\title{
GEOLOGICAL SURVEY OF CANADA,
}

ALFRED R. C. SELWYN, F.G.S., DIRFCTOR.

REPOP|T me is Anewn|

ax TIIK

$4 \ldots+\cdots, 1023$

FOSSIL PLANTS

nF THF.

LOITER CARBONIFEROUS AND MILISTONE GRIT

FORMATTONS OF CANADA.

$\mathrm{BI}$

J. W. DATSON, LL.D., F.R.S., F.G.S.

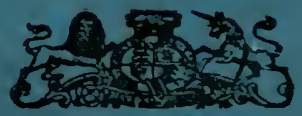

MONTREAL :

PRIN'TED BY JOHN LOVELL, ST. NICHOLAS STREET. -

1873. 
THE LIBRARY

BRIGHAM YOUNG UNIVERSITY

PROVO, UTAH 
Digitized by the Internet Archive in 2010 with funding from Brigham Young University 



GEOLOGIOAL SURVEY OF CANADA, ALFRED R. C. SELiWyN, F.G.S., Director.

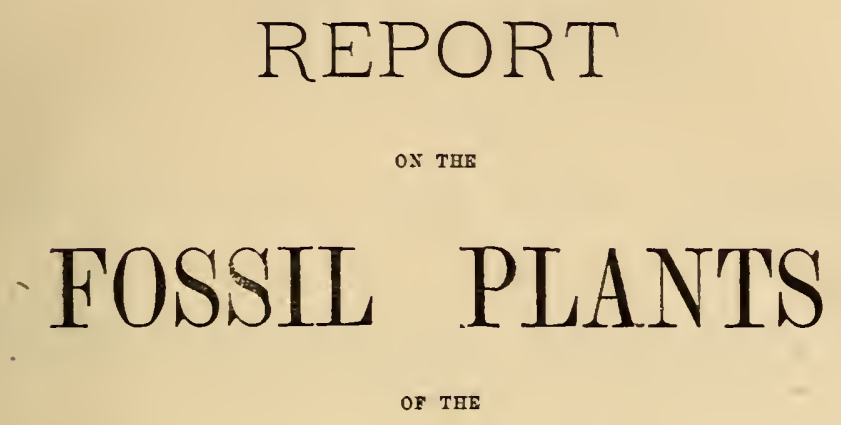

LOWER CARBONIFEROUS AND MILLSTONE GRIT FORMATIONS OF CANADA.

J. W. DAWSON, LL.D., F.R.S., F.G.S.

MONTREAL :

PRINTED BY JOHN LOVELL, ST. NICHOLAS STREET. 
THE LIBRARY

BRIGHAM YOUNG UNIVERSITY

PROVO, UTAH 


\section{REPORT \\ ON THE \\ FOSSIL LAND PLANTS \\ OF THE}

\section{LOWER CARBONIFEROUS AND MILLSTONE GRIT FORMATIONS OF CANADA.}

BY J. W. DATSON, LL.D., F.R.S., F.G.S.

To Alfred R. C. Selwyn, Esq., F.G.S.,

Director of the Geological Survey of Canada.'

SiR,

The present Report may be regarded as a sequel to that of 1871 , on the Flora of the Devonian and Upper Silurian.

It will serve to characterise by vegetable fossils the beds which form the lower members of the Carboniferous System, and to distinguish these lower or "False" Coal-measures from the Devonian on the one hand and the Middle or Productive Coal-measures on the other.

It will also serve to illustrate the Flora of a somewhat obscure and neglected part of Palrozoic time, that which constitutes the dawn of the Carboniferous Period.

To facilitate comparison, until a detailed Report on the more extensive Flora of the Middle and Upper Coal-formations can be issued, I have added a catalogue of the plants of those formations.

I have the honour to be,

Your obedient servant, J.,W. DAIVSON.

McGill College, Montreal, June 10, 1873. 


\section{UONTENTS.}

I. Introductory sketch of the Geology of the Lower Carboniferous Coal Measures and Millstone Grit, with the equivalent formations abroad.

II. Descriptions of the Plants of the Lower Carboniferous Coal Measures.

III. Descriptions of the Plants of the Millstone Grit.

1V. Catalogue of Plants of the Middl 3 and Upper Coal Formations.

$\nabla$. Note on the external characters of Lepidodendroid and Sigillaroid trees.

VI. Appendix-New Sizillariae and Lepidodendron. 


\section{INTRODUCTION.}

THe formations to which this Report relates extend from the Lorrest Carboniferous Beds upward to the equivalent of the Millstone Grit inclusive, and underlie the Middle or Productive Coal-formation.

In the region under consideration they overlie unconformably the Devonian beds of which the Flora was described in my Report of 1871, as well as the Upper Silurian and other older Formations.

The term Lower Carboniferous as used in this Report is, therefore, equivalent to Sub-Carboniferous of some American geologists, and designates a group of beds distinguished both stratigraphically and by fossils from the Devonian or Erian below, passing into the Coal-formation above, and properly included mithin the Carboniferous system, of which its basal portion forms the lowest member, while its upper portion immediately underlies the Mililstone Grit, which may be regarded as forming the transition from the Lower Carboniferous proper to the Middle Coal-formation.

Where most fully developed in Nova Scotia and Nerw Brunswick, these formations may be thus sub-divided in ascending order :-

1st. The Horton Bluff Series or Lower Carboniferous Coal-measures, consisting of hard sandstones and shales often calcareous, associated with conglomerate and grit, and in some places with highly bituminous shales. They contain underclays and thin coaly seams, remains of Plants, Fishes and Entomostracans, and foot-prints of Batrachians, but no strictly marine remains. This group was first established as a distinct sub-division of the Carboniferous in Nova Scotia, by Sir C. Lyell and the writer in 1843 and 1847.

2nd. The Windsor Series, or Lower Carboniferous Limestone and Gypsiferous Beds. This is a marine formation holding characteristic shells and corals of the Lower Carboniferous period, and containing in addition to the limestones thick beds of sandstone, marl and clay, usually red, and of gypsum. First defined by Sir C. Lyell in $18+3$. 
3rd. The Millstone Grit Series, consisting of sandstones and shales, often red, and conglomerate, associated with dark coloured beds holding fossil plants and Naiadites, and with a few underclays and thin seams of coal. The name Millstone Grit was first applied to these as a distinct group by Mr. R. Brown in 1844. The group was distinctly indicated in Sir W. E. Logan's section of the South Joggins in 1843, and in my paper of the same year on the Lotrer Carboniferous Rocks of Eastern Nova Scotia.

4th. Above these are the Middle Coal-formation and the Upper or Newer Coal-formation.

The three lower members are thus described in "Acadian Geology," where will also be found an account of the fossils discorered in them up to 1868, and many local details :-

"The Lower Carboniferous Coal measures, or Lower Coal measures.In some localities these resemble in mineral character the true coal measures. In others they present a great thickness of peculiar bituminous and calcareous shales. They usually contain in their lower part thick beds of conglomerate and coarse sandstone, which in some places prevail to the exclusion of the finer beds. The characteristic plants of these beds are Lepidodendron corrugatum and Cyclopteris Acadica, with Dadoxylon antiquius. They also contain locally great quantities of remains of fishes, and many Entomostracans, among which are Leaia Leidyi and an Estheria, also Leperditia subrecta, Portlock, Beyrichia colliculus, Eichw., and a Cythere.

This formation is not everywhere distinguishable at the base of the Carboniferous, and is variable in its characters. It is seen in southern Cape Breton, in the county of Sydney, and in Hants; but its most remarkable and interesting exposures are at Horton Bluff, and at Hillsborough and other places in southern New Brunswick. In the last mentioned locality, it affords the remarkable bituminous mineral known as Albertite."

"The Lower Carboniferous Marine Formation.-The essential features of this formation are thick beds of marine limestone, characterized principally by numerous brachiopods, especially Productus Cora, P. semireticulatus, Athyris subtilita, and Terebratula sufflata, with other marine invertebrates. Associated with these limestones are beds of gypsum, and they are enclosed in thick deposits of sandstone, clay and marl, of prevailing red colours.

The thickness of this formation seems to be very variable, and in some districts it is represented almost entirely by conglomerates, while in others it abounds in limestone and gypsum. It is very largely developed in Hants and Colchester counties, and rises from beneath the Millstone Grit 
in Cumberland, Pictou, and Cape Breton. Smaller areas occur in several other parts of the province of Nora Scotia, and it is extensively developed in New Brunswick. It affords all the gypsum exported from Nova Scotia and New Brunswick."

"The "Millstone Grit" Formation.-This name, though not in all cases lithologically appropriate, has been borrowed from English geology to designate the group of sandstones, shales, and conglomerates, destitute of coal, or nearly so, and with few fossil plants, which underlies the coal measures. In its upper and middle part it includes thick beds of coarse gray sandstone holding prostrate trunks of coniferous trees (Dadoxylon Acadianum). In its lower part, red and comparatively soft beds prevail. This formation is exposed in the same localities with the Middle Coal formation, and especially in the south Joggins section, where it attains to the enormous thickness of between 5000 and 6000 feet."

In some localities the lower member is absent, the marine limestones resting on the older rocks. In other localities the marine member is absent or very slenderly developed and the Lower Carboniferous Coal-measures and Millstone Grit are united together. In this case, however, the lower series is usually represented by coarse conglomerates with few fossils.

\section{Equivalent Formations Abroad.}

This is a subject of some importance, more especially with respect to the Horton series or Lower Carboniferous Coal-measures, as errors have been committed both in the way of confounding these with the Coal-measures above and with the Devonian below ; and in works of general geology very little attention is usually given to them as a distinct group. With regard to the Marine Limestones, their equivalency to the Lower Carboniferous Limestones of other countries is undoubted. The Millstone Grit also admits of very little difference of opinion as to its equivalents. In the following lists I have given the equivalents of the Horton series and Millstone Grit series as they appear to me to be settled by stratigraphy and fossils.

1. Equivalents of the Lower Carboniferous Coal Measures or Horton Series.

(1). The Vespertine Group of Rogers in Pennsylvania.

(2). The Kinderhook Group of Worthen in Illinois.

(3). The Marshall Group of Winchell in Michigan.

(4). The Waverley Sandstone (in part) of Ohio.

(5). The Lower or False Coal Measures of Virginia.

(6). The Calciferous Sandstones of McLaren, or Tweedian Group of Tate in Scotland.

(7). The Carboniferous Slate and Coomhala Grits of Jukes in Ireland.

(8). The Culm and Culm Graywacke of Germany.

(9). The Graywacke or Lower Coal-measures of the Vosges, as described by Schimper. 
(10). The Oider Coal-formation of the Ural, as described by Eichwald.

(11). The so-called "Ursa Stage" of Heer includes this, but he has united it with Deronian beds, so that the name cannot be used except for the local derelopment of these beds at Bear Island, Spitzbergen.

All of the above groups of rocks are characterised by the prevalence of Lepidodendra of the type of L. corrugatum, L. Veltheimianum and $L$. Glincanum; Pines of the sub-genus Pitus of Witham, Palaeoxylon of Brongniart; and peculiar Ferns of the genera Cyclopteris, Cardiopteris and Sphenopteris. In all the regions above referred to they form the natural base of the great Carboniferous System.

\section{Equivalents of the Millstone Grit Series.}

1. The Seral Conglomerate of Rogers in Pennsylvania, \&c.

2. The Lower Coal formation Conglomerate and Chester Groups of Illinois (Worthen.)

3. The Lower Carboniferous Sandstone of Kentucky, Alabama and Virginia.

4. The Millstone Grit and Yoredale Rocks of Northern England, and the Culmiferous of Deronshire.

5. The Moor rock and Lower Coal Measures of Scotland.

6. Flagstones and Lower Shales of the South of Ireland and Millstone Grit of the North of Ireland.

7. The Jungste Graywacke of the Hartz, Saxony and Silesia.

The vegetable fossils of this Group differ from those of the beds below the Marine Limestones, and contain forms resembling or identical with those of the Middle Coal-formation, into which indeed both lithologically and as to fossils the Millstone Grit passes by imperceptible gradation.

\section{Distribution in New Brunswick, Nova Scotia and Lower Canada.}

Under this head I shall very shortly sketch the geographical arrangement of the formations in question, referring to previously published memoirs and reports for details.

In Gaspé and the Bay de Chaleur and along the northern margin of the New Brunswick Carboniferous District, the Lower Carboniferous Formation presents the characters of the Bonaventure Formation of Sir William Logan : the marine limestones being absent or little developed, and the prevailing rocks being conglomerates and sandstones with few fossils. (Logan, Report of 1863. Robb, Report of 1869. Acadian Geology, P. 227.)

In Southern New Brunswick the Lower Carboniferous Coal-Measures are remarkable for the great thickness of bituminous and bitumino-calcareous shales which they contain. These rocks hold the remarkable vein of Albertite worked in this district. They contain numerous remains of fishes and also of the characteristic Lower Carboniferous plants. (Bailey and Matthew, Report of 1871. Acadian Geology, P. 231.) 
In Southern New Brunswick and North Western Nova Scotia the Millstone Grit is also largely developed. At the South Joggins, where this formation and the Middle Coal-formation probably attain their maximum thickness, the equivalent of the Millstone Grit occupies in Sir William Logan's section a vertical thickness of no less than 5972 feet, and consists of red and gray sandstones, red and chocolate shales and conglomerates with some dark shales, underclays, bituminous limestones and thin unproductive coals. It contains species of Sigillaria, Lepidodendron, Calamites, Dadoxylon and Cordaites. (Logan, Geol. Survey of Canada, 1845. Acadian Geology, P. 176.)

On the south side of the Cumberland coal-field, the Lower Carboniferous beds appear to return to the type of the Bonaventure formation, and to consist principally of conglomerate and sandstone not rich in fossil plants, and these principally of the Millstone Grit horizon.

Crossing the ancient metamorphic ridge of the Cobequids, we find on their southern flanks conglomerates representing the lowest Carboniferous rocks. Above these there is a slender developement of the marine limestones and a great thickness of hard sandstones and shales representing the Millstone Grit and perhaps the lower part of the Middle Coal-formation. These rocks form a long belt extending from Cape Chiegnecto till it unites with the Pictou Coal-field on the eastward. Their general arrangement appears to be that of a narrow trough much broken by faults. They afford a good representation of the Flora of the Millstone Grit. (Acadian Geology, P. 263 et seqr.)

On the south side of Minas Basin and Cobequid Bay a very wide area is occupied by Lower Carboniferous Rocks; and at the cliff of Horton Bluff and other places in its vicinity, these beds which, from their large development in this locality may be named the Horton Series, are very well exposed and contain abundance of their characteristic fossils. For their detailed description I may refer to my paper of 1858, Journal of Geol. Society, Vol. XV., P. 63. (See also Acadian Geology, P. 252.)

Similar rocks are seen and have been described by the author near Windsor, at Walton and Noel, and at Five Mile River on the Shubenacadie, in all these places rising up from under the Lower Carboniferous limestones. (Journal of Geol. Society, Vol. IV., P. 59: Vol. VII., P. 335 ; Acadian Geology.)

Further East, on the Salmon River, and on the West, Middle and East Rivers of Pictou, there is a great development of rocks of the Millstone Grit Series, consisting largely of chocolate sandstones and shales, often very hard and with bands of gray and dark-coloured beds holding plants. In this region the marine limestones extend upward into the Millstone 
Grit, so that it is difficult to establish any distinct line of separation, and the Lower Carboniferous coal measures seem to be absent. (Journal of Geol. Society, Vol. I., P. 26, 1843. Logan and Hartley, Reports on Pictou Coal-Field, 1869. Acadian Geology, P. 316 et seqr.)

In the Pictou coal-field there are certain hard sandstones holding obscure fossil plants which come up from beneath the Millstone Grit on the Middle River, and which I have regarded as Devonian. It is, however, barely possible that they may represent the Lower Carboniferous Coal-measures, otherwise wanting in this district.

The great and exceptional conglomerate of the Pictou coal district, known as the New Glasgow Conglomerate, appears to be a shingle bed of the UpperMillstone Grit or Middle Coal-formation epoch. It stretches with some interruptions from Merigomish to Roger's Hill and Mt. Dalhousie near the Eastern end of the Cobequid Ridge, or about twenty miles, and is undoubtedly connected with the different development of the beds of the Coal-formation on the South and North of this line; and it implies very great and violent denudation of the Lower Carboniferous sandstones during the Coal-formation period, as the fragments contained in it are largely composed of these sandstones, and are often of great size. (Acadian Geology, P. 321 et seq. Logan, Report on Pictou, 1869.)

At the extreme eastern end of the Pictou coal-field, where it is in contact with the Upper Silurian at McCara's Brook, the Lowest Carboniferous beds are conglomerates with interstratified trap, above "which is marine limestone overlaid by the Millstone Grit Series. (Journal of Geol. Society, Vol. I., P. 329. Acadian Geology, section opposite Page 125).

In the carboniferous area of Antigonish County we again meet with the dark shales and sandstones of the Horton Group, holding their characteristic plants and underlying the marine limestones and gypsums. I noticed these beds as occurring at Right's River in 1843, * and Dr. Honeyman, who subsequently traced them further to the Eastward, has kindly placed in my hands a small but interesting collection of their fossil plants.

The long belt of Carbonferous Rocks extending along the West Branch of the St. Mary's River, has the mineral character and fossils of the Millstone Grit Series in those places where I have examined it, except near Guysboro, where there are Lower Carboniferous limestones, and in the Strait of Canso, near C. Porcupine, where the basal conglomerates appear. (Acadian Geology, P. 350).

In Cape Breton a well-characterised representation of the Lower Carboniferous Coal-measures or IIorton Series is seen in the sandstones, gray

* Journal Geol. Society, Vol. I., Page 329. 
and black shales and conglomerates which underlie the limestone and grpsum of Plaister Cove, while the Millstone Grit seems to be represented by the thick sandstones underlying the Coal-field of Richmond County. (Journal of Geological Society, Vol. V.; Acadian Geology, P. 390 et seqr.)

In Northern Cape Breton, from the Cape Dauphin section, as described by Mr. R. Brown, it would appear that the Lower Carboniferous Coalmeasures are slenderly represerited or concealed by faulting. Mr. Brown has, however, recognised the Millstone Grit as underlying the Sydney and Glace Bay Coal-fields, and attaining to a thickness of 1800 feet. It consists largely of gray sandstone, and holds Sigillariae, Calamites and Lepidodendra, (Brown, Journal Geol. Socicty, Vol. III, P. 258. Ibid. Vol. VI., P. 116.)

From a collection of fossils made by Mr. R. Bell in Western Newfoundland and presented to the Museum of the McGill University by Donald Ross, Esq., it appears that the Lower Carboniferous limestone of that Island holds the same fossils with that of Nova Scotia, and that it is overlaid by a series of beds corresponding to the Millstone Grit. This formation, however, contains beds of coal of workable size, abounding in remains of Lepidodendra, so that it would seem that in Newfoundland, as in Scotland, the workable coals extend farther domn in the series than is the case to the southward.

The following table will clearly show the relations of the formations in question in the more important localities referred to above : 


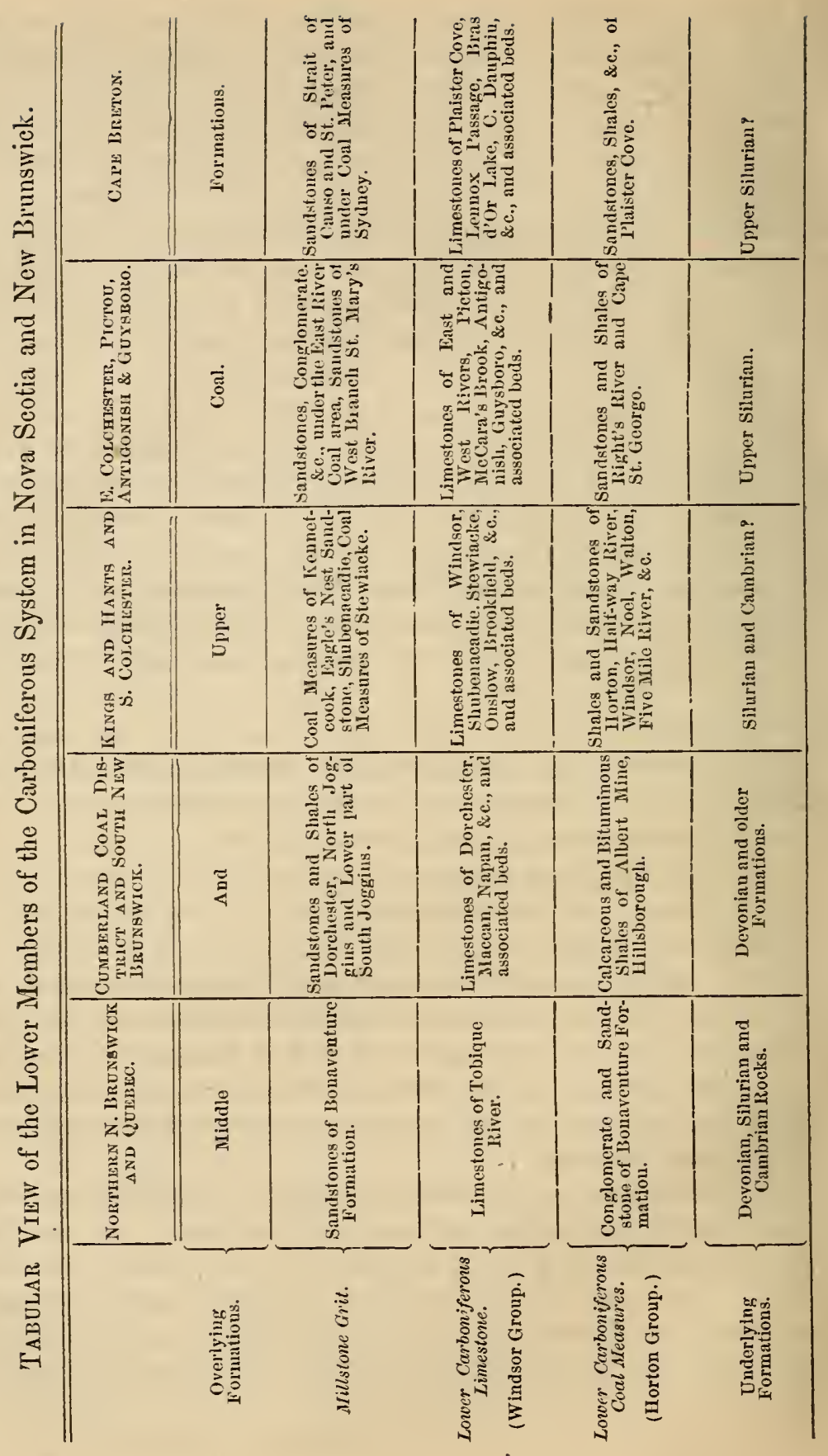


The above introductory details are rendered necessary by the doubts and obscurity in which the Iower Carboniferous plant-bearing beds have been involved. I would only farther make the following general remarks.

1. Lines of separation between the different members of the Carboniferous must necessarily to be some extent arbitrary, and may differ in different localities.

2. Wherever the marine members of the system are developed, a marked difference is observable in the flora under and above those members, depending on the time during which the area was submerged; but where the marine members are not developed, a gradual passage in the flora may be observed.

3. Marine limestones occur locally even in the Upper Coal-formation, and these must of course not be confounded with the true Lower Carbonifercus limestones. I have also suggested in Acadian Geology that in those parts of Nova Scotia where the marine limestones are largely developed in thickness, as in Hants county, they may possibly encroach on the time elsewhere occupied by the Millstone Grit and Middle Coal formation, just as in other localities, as at Salmon River, where the Millstone Grit is largely developed, isolated beds of limestone sometimes occur in its upper part.

4. In the area to which this report relates, the close of the Devonian was accompanied by great physical changes which removed the Devonian flora. In the Lower Carboniferous period a meagre flora different from that of the Devonian took possession of the land. 'This was again partially removed by the subsidence leading to the deposition of the Lower Carboniferous limestones, and the Millstone Grit lying on these, forms, as to its flora, the dawn of the great Middle Coal-formation.

5. While the local elevation, subsidences and denudations within the Carboniferous period were sufficient to cause some limited cases of unconformability*, these are not comparable with those between the Devonian and the Carboniferous; and the Devonian fauna and flora are as a whole quite distinct from those of the Carboniferous, $t$ though there are some species of plants common.

6. In Eastern America, as in Great Britan, the conditions of coal accumulation seem to have set in earlier to the Northward. The coal beds of Newfoundland belong to the Millstone Grit series. Those of Pictou are exclusively in the Middle Coal series, and apparently in its lower part. Those of the Joggins seem to be rather higher in the series than those of

* Journal of Geol. Society, Vol. 1, P. 32, Bailey's Report on New Brunswick; Acadian Geology, P. 150, section.

$\dagger$ For illustrations of the Devonian and Carboniferous fana in the arza in question, 1 may refer to the_Reports of Mr. Billings and to my Acadian Geolozrs. 
Pictou, and in the United States there are workable beds of coal in the Upper-Coal measures which are barren in Nova Scotia. This connects itself with the factillustrated in my previous Report on the Devonian flora, that this flora in North America seems to have extended itself from the north east; a view which Heer and Prof. Asa Gray seem also to entertain with respect to the Tertiary floras.

7. The following remarks on the Lower Carboniferous Plant-beds, published in 1858, * should perhaps be reproduced here:-

"In Nova Scotia these older coal-measures, as compared with the true coal-measures, are more calcareous, abound more in remains of fishes, and have fewer vegetable remains and indications of terrestrial surfaces. They occur generally along the margin of the coal-areas, near their old shores; and as we might expect in such circumstances, they are associated with, or replaced by beds of conglomerate derived from the neighbouring highlands of Silurian and Devonian rocks. Where these conglomerates are absent, we usually find very frequent alternations of sandstones with sandy and calcareous shales, giving a homogeneity of appearance, together with, at the same time, very frequent changes and differences in mineral character. The general aspect is that of muddy estuarine deposits, very slowly accumulating, and cliscoloured and darkened by decaying organic substances, partly of aquatic, and partly of terrestrial origin.

"Both the supply of sediment and the growth and preservation of vegetable matter were on a smaller scale than in the coal-period, the only exception being the bituminous limestone and associated dark shales of the latter, which in composition and aspect often much resemble the beds now under consideration.

"These characters cause the Lower Carboniferous coal-measures to present a very striking contrast with the coarse and often reddish sediments which prevail in the marine parts of the Lower Carboniferous series in the area in question.

"Before leaving this comparative view, it is necessary to remark that it is precisely in those districts where the true coal-measures are least developed that the lower series is most important. This is not likely to be the result of accident. It shows that the physical and vital conditions of the coalmeasures originated as early as those of the mountain-limestone, that locally these conditions may have been contemporaneous throughout the whole period, but that in some localities the estuary and swamp-deposits first formed were so completely submerged as to be covered by marine deposits, while in others early marine beds were elevated and subjected to the conditions of gradual subsidence and filling up indicated in the great coal-measures of the South Joggins, Pictou and Sydney."

\footnotetext{
- Journal of Geol. Society, Vol. XV.
} 


\section{PLANTS OF THE HORTON SERIES OR LOWER CARBO. NIFEROUS COAL MEASURES.}

\section{Coniferce.}

\section{DADOXYLON, Endlicher.}

Trunks of coniferous trees are found in all the geological formations from the Lower Devonian to the Modern, and in almost every case separated from the foliage and fruit. Hence they have to be classified separately; and botanists, attaching little value to the characters of the merely vegetative organs of plants, have in general given them little attention. Goeppert has, however, by an elaborate investigation established a systematic classification of some coniferous moods, which Kraus and others have endeavoured to modify and improve.

The difficulties arise mainly from the great similarity in the rood of somewhat distinct types of conifers, and the differences which are due to the different states of preservation of the specimens of the same species of wood. These difficulties can be overcome only by careful and multiplied microscopic examinations of numerous examples of wood recent and fossil, and of the latter in different states of preservation. In this place we may confine ourselves to the consideration of the Lower Carboniferous species, and those more nearly allied to them.

Witham in 1833 described several Carboniferous species of pine wood, under the generic name $P$ inites, separating under the name Pitus species which appeared to have the disks on the cell-walls separate and in transverse lines. Witham's name was changed by Goeppert to Araucarites, to indicate the similarity of these woods to Araucaria, Pinites being reserved for trees more closely allied to the ordinary Pines. Endlicher, restricting A raucarites to foliage, \&c., of Araucaria-like trees, gave the name Dadoxylon to the wood ; and this, through Unger's "Genera and Species," has gained somewhat general acceptance. Endlicher also gave the name Pissadendron to the species which Witham had called Pitus; but Brongniart proposed the name Palaeoxylon to include all the species with thick and complex medullary rays, whatever the arrangement of the discs. In Schimper's new work Kraus substitutes Araucaroxylon for Endlicher's Dadoxylon, and includes under Pissadendron all the species placed by Brongniart in Palaeoxylon.

To understand all this confusion, it may be observed that the characters 
available in the determination of Palaeozoic coniferous wood are chiefly the form and arrangement of the wood-cells, the character of the bordered pores or discs of their walls, and the form and composition of the medullary rays.

The character on which Witham separated his genus Pitus from Pinites is, as I have ascertained by examination of slices of one of his original specimens kindly presented to me by Mr. Sanderson of Edinburgh, dependent on state of preservation, the imperfectly preserved discs or areolations of the walls of the fibre presenting the appearance of separate and distinct circles, while in other parts of the same specimens these discs are seen to be contiguous and to assume hexāgonal forms, so that in this respect they do not really differ from the ordinary species of Dadoxylon. The true character for subdividing those species which are especially characteristic of the Lower Carboniferous, is the composite structure of the medullary rays, which are thick and composed of several radial piles of cells placed side by side. This was the character employed by Brongniart in separating the genus Palaeoxylon, though he might with convenience have retained Witham's name, merely transferring to the genus the species of Witham's Pinites which have complex medullary rays.

The following table will clearly show the distinctive characters and relations of the genera in question, as held by the several authors above referred to:-

Wood of Palcozoic Conifers.

\begin{tabular}{|c|c|c|c|}
\hline WoOdx Fibres. & MeddLlary Raxs. & GeNeric NaMES. & GEOLOGICAL AGE. \\
\hline No Discs. & $\begin{array}{l}\text { One or two Series of } \\
\text { Cells. }\end{array}$ & Aporoxylon, Unger. & Devonian. \\
\hline $\begin{array}{l}\text { Spiral ligneous lining, } \\
\text { Discs few or none. }\end{array}$ & $\begin{array}{l}\text { Uncertain, probably } \\
\text { composite. }\end{array}$ & Prototaxites," Dawson. & Devonian. \\
\hline \multirow{2}{*}{$\begin{array}{l}\text { Dises in one Series con- } \\
\text { tiguous, or in several } \\
\text { Series spirally ar- } \\
\text { ranged. }\end{array}$} & $\begin{array}{c}\text { Complex or of two or } \\
\text { more Series of Cells. }\end{array}$ & $\left\{\begin{array}{l}\text { Pitus, Witham. } \\
\text { Palooxylon, Brongniart. } \\
\text { Pissadendron, Endlicher. }\end{array}\right.$ & $\begin{array}{l}\text { Middle \& Lower Car- } \\
\text { boniferous and De- } \\
\text { vonian. }\end{array}$ \\
\hline & $\begin{array}{l}\text { Simple or of one Row } \\
\text { Cells. }\end{array}$ & $\left\{\begin{array}{l}\text { Araucarites, Goeppert. } \\
\text { Dadoxylon, Endlicher. } \\
\text { Araucaroxylon, Schimper. }\end{array}\right.$ & $\begin{array}{l}\text { Upper Carboniferous } \\
\text { and Permian. }\end{array}$ \\
\hline
\end{tabular}

*The criticisms of Mr. Carruthers on this genus, I purpose to meet in a proper manner elsewhere. 
The two first genera above named are not known to ascend above the Devonian. The third begins as far as known in the Middle Devonian and extends to the Middle Carboniferous. The fourth begins in the Middle Carboniferous and extends to the modern world. The true Dadoxylons have large transversely floored pith-cylinders of the type of Sternbergia, and this is also known to have been the case with some species of the Palaeoxylon group. As I have elsewhere shown, there is reason to believe that the foliage of the true Dadoxylons was that known to Botanists as Walchia (Report on Prince Edward Island, 1871), and especially characteristic of the Upper Carboniferous and Permian.

In Nova Scotia D. (Palaeoxylon) antiquius is characteristic of the Lower Carboniferous Coil measures; $D$. (Palaeoxylon) Acadianum of the Millstone Grit and Midule Coal formation, and D. materiarium of the Upper Coal formation. $D$. antiquius, described below, is of precisely the same type with Witham's Pitus antiqua and $P$. primaeva from the same horizon (Tweedian) in Scotland, but is specifically distinct.

Dadoxylon (Palaeoxylon) antiquius, Dawson.-Plate I. Figs. 1 to 5. (Cand. Nat. Vol. VIII., 1863. Journal of Geol. Society of London, May 1866. Acadian Geology, P. 473 \& 425.)

Description.-Wood-cells narrow, thick-ralled, with two or three rows of discs, which are contiguous, alternate and hexagonal, and contain oval oblique pores. Medullary rays of three or four series of cells with twenty or more superimposed, nearly as wide as the woorl-cells. Rings of growth indistinct but visible.

This species differs from Pitus (Palaeoxylon) antiqua of Witham in its longer and narrower medullary rays, and its narrower wood-cells with smaller pores and thicker walls. It is a distinct though closely allied species.

It is unfortunate that I have given a epecific name approaching so nearly to that of Witham; but as the species are closely allied and discoveries of their other organs may necessitate different names, I think it better to leave it for the present.

The wood-cells of this species present in the cross-section that thickwalled appearance and rotundity of the cavity of the cells which causes them to appear to have intercellular matter and to resemble Prototaxites or very young taxine twigs. Detailed comparisons, however, lead me to believe that this results neither from any distinct structure interposed between the fibres nor from any proper lining of the cell-walls, but that it is an effect of long maceration in water, causing a swelling of the cell-walls,so that specimens of the same wood differently preserved may either appear with 
thickened cell-walls, cylindrical or nearly so, or with square and comparatively thin-walled cells or fibres.

The only specimen of this species at present in my collection is a fragment of a trunk collected by the late Dr. Harding at Horton, and showing neither the pith nor the outer bark. No other parts of the tree have in so far as I am aware been found.

The figures show magnified camera tracings without any reference to pictorial effect.

\section{Sigillarice.}

I have as yet found no well characterised stems or leaves of Sigillariæ in the Lower Carboniferous Coal-measures. The old stems of Lepidodenaron corrugatum in certain states assume a vertically ribbed appearance, but this has no connection with the true ribs of Sigillarix, being only a vertical cracking of the bark, owing to the expansion of the stems. It occurs also in the Cyclostigma of the Upper Devonian of Ireland.

One small and fattened specimen of fossil wood found at Horton Bluff, has the characteristic rariporous tissues of Sigillaria, but it shows none of the external markings. I have figured its structure in Fig 6 .

Specimens of the ordinary Stigmaria ficoides are found at Horton Bluff, and also at Five-mile River, and also the variety stellat $a$ with radiating marks around the areoles. A fine specimen of this last was in the collection of the late Dr. Harding of Windsor, but I have not now access to it.

The Stigmarix figured in Plate IV, I believe from their associations to belong to Lepidodendron, but it is not at present possible to distinguish by external characters alone the Stigmarix of this genus from those of Sigillariæ.

Eichwald mentions as fossils of the Lower Carboniferous of Russia, $S$. reniformis and the stellate and ordinary varieties of Stigmarie.

\section{Equisetacece.}

Calamites.

Small stems of a Calamite, apparently C. cannaeformis, or C. transitionis (radiatus) are the Lower Carboniferous of Horton. 


\section{Lycopodiacece.}

LEPIDODENDEON.

Lepidodexdron corregatum, Darson.-Plates II, III, IV. Plate V, Figs. 33 to 36 \& 38 .

(Quarterly Journal of Geological Society, Vol. XV. Acadian Geology, P. 451.)

\section{Description:-}

Hatit of grouth.--Somewhat slender, with long branches and long slender leares haring a tendency to become horizontal or drooping.

Markings of Stem.-Leaf-bases disposed in quincunx or spirally, elongate, orate, acute at both ends, but more acute and slightly oblique at the lower end ; most prominent in the upper third, and with a slight vertical ridge. Leaf-scars small, rounded, and showing only a single punctiform vascular scar. The leaf-scar on the outer surface is in the upper third of the base; but the obliquity of the vascular bundle causes it to be nearly central on the inside of the epidermis. In young succulent shoots the leaf-scars are contiguous and round as in Cyclostigma, without distinct leaf-bases (Fig. 33). In this state it closely resembles $L$. Olivieri, Eichwald. *

In the ordinary young branches the leaf-scars are contiguous, and closely resemble those of $L$. elegans Brongt. (Fig. 13). As the branches increase in diameter the leafscars siightly enlarge and sometimes assume a verticillate appearance (Figs. 14, 15). As they still farther enlarge they become separated by gradually increasing spaces of bark, marked with many waving strix or wrinkles, (Figs. 16 to 20.) At the base of old stems the bark assumes a generally wrinkled appearance without distinct scars (Figs. $21 \& 32$.)

The forms represented in Figs $34,35,36$, I was at first disposed to regard as specifically distinct; but I now think they may be merely varietal. Fig. 36 shows a ribbed appearance, and the scars arranged in vertical rows. It may be compared with the Knorria form, Fig. 29. It is deserving of remark that the inner surface of the epidermis in the old stems is more delicately corrugated than the outer surface.

Knorria or decorticated states.-Of these there is a great variety, depending on the state of preservation, and the particular

- Lethaea Rossica Plate Y, Figs. 12, 13. 
layer of bark forming the actual surface. Fig. 24 shows the common Knorria form with the leaf-bases represented by longitudinal ridges. Fig. 26 shows a form in which the rascular bundles appear as cylindrical truncate projections. Fig. 27 shows the leaf-bases prominent, and Fig. 27 and 28 show the appearance of Iongitudinal ribbing produced by the expansion of the bark. Fig. 32 shows the decorticated base of an erect stem. Fig. 38 shows one of the deeper layers of the bark with leaf-scars of a transverse form, the ordinary form being seen in the lower part of the same specimen.

Structure of Stem. - This is not perfectly preserved in any of my specimens, but one flattened specimen shows a central medulla with a narrow ring of scalariform vessels surrounding it, and constituting the woody axis. The structure is thus similar to that of $L$. Harcourtii, which I regard as probably the same with the closely allied European species $\dot{L}$. Veltheimianum.

Leaves.-These are narrow, one-nerved, curving somewhat rapidly outward, Figs. 10, 11, 12, 23, 25. They vary from one to two inches in length.

Roots.-I have not seen these actually attached, but they occur very abundantly in the underclays of some erect forests of these plants at Horton Bluff, and are of the character of Stigmarix, Figs. 30, 31. In some of the underclays the long flattened rootlets are excessively abundant, and show the mark of a central vascular bundle.

Fructification.-Cones terminal, short, with many small acute imbricate scales. Spore-cases globular, smooth (Figs. 10, 22.) On the surface of some shales and sandstones at Horton there are innumerable round spore-cases of this tree about the size of mustard seed, Fig. 22. Large slabs are sometimes covered with these, and thin layers of shale are filled with flattened specimens.

This is the characteristic species of the Lower Carboniferous Coal-measures, occurring in great profusion at Horton Bluff and its vicinity, also at Sneid's Mills near Windsor, Noel and Five-Mile River, at Norton Creek and elsewhere in New Brunswick (Matthew's Col.), and at Antigonish (Honeyman's Col.)

I have received from the lowest carboniferous beds of Ohio specimens of this species.* According to Rogers and Lesquereux similar species

* Journal of Geo. Society, Nov. 1862, P. 313. 
exist in the Vespertine of Pennsylrania, associated with Stigmaria. L. obssurum, Les, from the Lower Carboniferous of Illinois resembles decorticated specimens of this species, and the fossil from the same region referred with doi'st by that author to $L$. Veltneimianum may be the same.

The Exropan equiraleats of this species are undoubtedly $L$. Glincanum, Eichwald, from the Lower Carboniferous of Russia, and L. Veltheimianum, Sternberg, from the Lower Carboniferous of Western Europe. So closely indeed does the last species resemble $L$. co:rugatum, that Schimper-and other European Palaeo-botanists conversant with the protean forms of these species anl kncring ours only by imperfect figures, may well be excused for regarding them as identical. They are undoubtedly related species of the same group, and in habit of growth $L$. corrugatum is in some respects intermediate between the others. Their differences will be seen in the following table:-

\section{Glincanum.}

Leaves. $\quad\{$ Long-linear, erect

Branches. $\left\{\begin{array}{l}\text { Stout. Leaf-bases elon- } \\ \text { gate, elliptic, contigu- } \\ \text { ous, with a strong keel. }\end{array}\right.$

Stems. $\quad\left\{\begin{array}{l}\text { Leaf-bases rers long, } \\ \text { larger than in next } \\ \text { species, narrowed at } \\ \text { extremities, separated } \\ \text { by narrow lines. }\end{array}\right.$

Old Trunks. $\left\{\begin{array}{l}\text { Leaf-bases widely se- } \\ \text { parated by corrugated } \\ \text { bark. }\end{array}\right.$

Leaf-scars. $\quad\{$ Round or oral with \{three rascular marks

Strobiles. $\quad\{$ Unknown.

Spore-cases. \{ Untanw 7.

Internal
structure. Unknown.
L. corrigatum.

Liuear, borizontal or curved downward.

Slender. Leaf-bases with a short keel, contiguous, elongate, ellip tic.

Leaf-bases long, acuminate below, separated by narrow lines.

Leaf-bases widely separated by corrugated bark.

Rhombic or rounded, rery small, only one distinct mark.

Small, with triangular scales.

Globular, smootli.

Type of $L$. Hurcourtii

\section{Veltineimianum.}

Linear, short, curred upward.

Slender. Leaf-bases elongate, rhombic, keeled.

Leaf-bases oblong, rhombic, acuminate, separated by narrow lines.

Leaf-bases slightly separated. Bark splitting in long gashes.

Transversely rhombic, with three rascular marks.

Long and cylindrical, scales elongate.

Probably globular.

L. Harcourtii, protably belongs to this species.

In the Knorria or decorticated states I do not think that these three species can be clearly distinguished. L. Glincanum, however, presents coarser markings than the others. In the above diagnoses I have relied for the European species mainly on the figures and descriptions of Eichwald and Schimper.

The relations of this plant to the Devonian Cyclostigma are of some interest. There can be no doubt that $L$. coriugatum, and its allies approach more nearly to Cyclostigma than do m ost of the other Carboniferous Lepi- 
dodendra. This resemblance consists in two facts. (1). The round shape of the young leaf-bases. (2). The expansion of the bark in such a manner in the course of growth as to separate the leaf-scars by finely corrugated spaces of epidermis, whereas, as I have elsewhere pointed out, " in the ordinary Carboniferous Lepidodendra the leaf-bases themselves expand with the growth of the stem or thes remain unchanged and become separated by deep gashes of the bark.

The differences, however, are more important. They are as follows:(1). In Cyclostigma the leaf-scars remain always round and unipunctate, and they never acquire leaf-bases properly so-called. The characters which exist only in young succulent stems of Lepidodendron corrugatum are persistent in Cyclostigma, which is thus an inferior form. (2). The strobiles of the Devonian Cyclostigma of Ireland are very different in the form of the scales from those of Lepidodendron, though the spore-cases are similar to those of the species now under consideration. (3). Cyclostigma is in so far as known confined to the Deronian period.

The above are the matured conclusions from careful examination of specimens from Ireland kindly communicated to me by Mr. Bailey. Heer and Carruthers also have argued this question in the Journal of the Geological Sociely, and are both in my judgment sometrhat in error, though in opposite senses. The former attaches too much importance to detached fragments of Cyclostigma, and is in error as to its geological horizon; the latter confounds Cyclostigma with Lepidodendra of the type of that now under discussion.

For some of my specimens of $L$. corrugatum I am indebted to $\mathrm{Mr}$. Matthew of St. John, Prof. Hartt of Cornell University, Mr. Elder late of Acadia College, Horton, and Dr. Honeyman.

Lepidodendron Sterneergir, Brongt. L. obovatum and L. dichotomum, Sternberg. Plate VI. Figs. 42 to 45 , and $42 \mathrm{a} \mathrm{b}$ and $44 \mathrm{a}$.

This species, as found in the Lower Carboniferous of Horton, was figured by mo under the above name in the Journal of the Geological Society, vol. XV, and such specimens as I have since obtained have confirmed the determination. Of the various forms referred to this species, my specimens resemble those figured by Schimper in plate LVIII, Fig. 4, and in plate LX, Figs. 3, 4, 5. They are identical with L. (Sagenaria) dichotomum as figured by Geinitz, in the Plants of the Coal-formation of Saxony, Plate III, Figs. 2 to 12.

It is, however, to be observed that the Horton specimens resemble $L$. Cottaii of Sauveur, in the only important point in which that species seems

- Journ. of Geol. Society, 1866. P. 713. 
to differ from $L$. Sternbergii, namely in the leaf-bases being truncated at the lower end. This may, however, be an accident of growth.

Though $L$. Sternbergii is found in the Lower Carboniferous, it is more abundant in the Middle Coal-formation. The specimens figured are from Horton. Fig. 43 represents a young branch, Fig. 42 a somewhat older branch, and Figs 44, 45 a still older stem in which the leaf-bases alone are preserved without the scars. The cone and scales represented in Fig. 41 may possibly belong to this species.

\section{LEPIDODENDRON TETRAGONUM, Sternborg.-L. quadrangulare, Unger.- Plate V. Fig. 39, 39 a.}

The species named $L$. tetragonum by Sternberg was founded on a specimen too badly preserved to show its distinctive characters, and Unger identifying this with another and possibly distinct species also described by Sternberg, has given the name quadrangulare to both. Geinitz has used the name for another species, possibly a Lepidophloios, and Goeppert has identified it with his $L$. sexangulare, which seems to include both a Lepidophloios and a Lepidodendron closely allied to, if not identical with

num. Schimper has mixed up my Lepidophloios tetragonus with Geinitz' Lepidodendron tetragonum, a totally distinct form, and with a species named by Presl quadrata and referred by him to his sub-genus Bergeri .

In the midst of this confusion I think it best to fall back on Sternberg's name, which certainly applies to something very near to the present species, and which I used to designate it in Acadian Geology and in my Synopsis of Carboniferous fossils in 1863. The characters of the genera Bergeria and Lepidophloios certainly do not apply to this plant. It is a true Lepidodendron, though with remarkably broad and regularly rhombic areoles. Unfortunately its leaves and fruit are unknown to me, though specimens of the bark of the stem have been obtained both from the Middle Coal-formation and Lower Carboniferous Coal-measures.

Its characters will be seen by a glance at Fig. 39. The leaf-bases are flat, of a rhombic form, approaching to square, and separated by deep and wide grooves. The leaf-scar is small and of the same form with the leaf-base, and situated quite at its upper end. In my specimensit shows only the central vascular mark. Lepidodrendra of this type are characteristic of the Lower Carboniferous in Europe as well as in America. Mr. Carruthers has figured a similar Lepidodendron collected by Mr. Daintree in Queensland, Australia, in rocks supposed by him to be Devonian. Mr. Selwyn has obtained similar specimens in the Carboniferous of Victoria; so that about the beginning of the Carboniferous period species of this group seem to have been very widely distributed. 
Lepidodendron fenestratum of Eichwald may be a decorticated form of a similar species, but if it shows the outer bark, it should perhaps be referred to Lepidophloios.

In comparison with this plant I have represented in Fig. 40 a specimen of a strobile deprived of its outer scales, and showing rhombic scars with a sub-central vascular mark. This strobile is from Horton and may be part of a mature fruit of $L$. corrugatum.

Lepidodendrox aculeatum, Sternberg. Plate V. Fig. 37, \& 37 a.

To this species I would refer the imperfectly preserved specimen from Horton figured in Plate V, Fig. 37. It is from the collection of Prof. Elder, and is clearly distinct from any of the above, and not distinguishable from specimens of $L$. aculeatum in a similar state from the Millstone Grit and Middle Coal-formation.

It will be observed that of the above four species, $L$. corrugatum is specially distinctive of the Lower Carboniferous, in which it is extremely abundant. The others are common to the Lower Carboniferous and true Coal-measures, and attain their maximum of abundance in the latter. Indeed, the specimens of them found in the Lower Carboniferous are so few that only extensive collection could have discovered them; and in this matter I am much indebted to the co-operation of Prof. Hartt and Prof. Elder, both of whom made large collections when resident in Horton, and have liberally given me access to them.

\section{Diplotegium. \\ Plate VI, Fig. 46, 46 a.}

To this genus I may with doubt refer the specimens one of which is represented in the figure above referred to. Similar plants in a better state of preservation and probably specifically distinct occur in the Middle Coal-formation.

It is difficult to form any opinion of the precise nature of these plants. They appear to have borne flat leaves or leaf-bases, and were probably allied to Lepidophloios. In Nora Scotia they are rare, and always, so far as I have seen, in small fragments.

\section{LyCOPODITES.}

Lrcopodites plunula. S. N. Plate I. Figz. 7, 8, 9.

Description.-Stems slender, branching, slightly corrugated or tuberculated, and bearing flat linear leaves either pinnate or 
apparently so owing to compression. The leaves are parallel-sided, obtuse and nerveless, and are slightly constricted and decurrent at the base. The tissues of the stem seem to have been dense and are carbonaceous, but show under the miscroscope only what appear to be remains of cortical cells. The specimens were collected by Rev. Dr. Honeyman in Lower Carboniferous shale near Springville on the East River of Pictou.

This plant belongs apparently to the same group of so-called Lycopodites with $L$. Vanuxemii of the Devonian of New York* and L. pennceformis, Goeppert, from the Jungste Grauwacke of Silesia. Filicites gracilis of Shumard from the Lithographic limestone of the Upper Devonian in Missouri is very similar. Whatever the nature of these curious fossils, they seem to be characteristic of the Lower Carboniferous and Upper Devonian.

The botanical relations of these plants must remain subject to doubt, until either their internal structure or their fructification can be discovered. In the mean time I follow Goeppert in placing them in what we must regard as the provisional genus Lycopodites. On the one hand, they are not unlike the slender twigs of Taxodium and similar Conifers, and the highly carbonaceous character of the stems gives some colour to the supposition that they may have been woody plants. On the other hand, they might in so far as form is concerned be placed with algae of the type of Brongniart's Chondrites obtusus, or the modern Caulerpa plumaria. Again, in a plant of this type from the Devonian of Caithness to which I have referred in a former memoir, the vernation seems to have been circinate, and Schimper has conjectured that these plants may be ferns, which seems also to have been the view of Shumard. The following remarks on this group of plants are copied from a paper by the author, on new Devonian plants, in the proceedings of the Geological Society, March 1871.

"In his recently published 'Paléontologie,' Schimper (evidently from inattention to the descriptions and want of access to specimens) doubts the Lycopodiaceous character of the species of this genus described in my papers in the Journal of this Society from the Devonian of America. Of these $L$. Richardsoni and L. Matthewi are undoubtedly very near to the modern genus Lycopodium. L. Vanuxemii is, I admit, more problematical ; but Schimper could scarcely have supposed it to be a fern or a fucoid allied to Caulerpa had he noticed that both in my species and the allied

- Report on Fossil plants of Deronian, \&c. Journal of Geol. Society, XVII, 314, P1 XVII. 
L. pennxformis of Goeppert, which he does not appear to notice, the pinnules are articulated upon the stem, and leave scars where they have fallen off. When in Belfast last summer I was much interested at finding in Prof. Thomson's collection a specimen from Caithness, which shows a plant apparently of this kind, with the same long narrow pinnæ or leaflets, attached, however, to thicker stems, and rolled up in a circinate manner. It seems to be a plant in vernation, and the parts are too much crowded and pressed together to admit of being figured or accurately described : but I think I can scarcely be deceived as to its true nature. The circinate arrangement in this case would favour a relationship to ferns; but some Lycopodiaceous plants also roll themselves in this way, and so do the branches of the plants of the genus Psilophyton."

Goeppert has described from the Carboniferous Limestone of Silesia* a plant which he names $C y c a d i t e s$ taxodinus, and which has some resem. blance to the above species; this plant has, howerer, a distinct midrib in each leaflet.

A resemblance also suggrests itself to Graptolites of the genus Rastrites but the structure and mode of preservation of these fossils show that they were not of the corneous nature of Graptolites. The somerwat problematical Buthograptus from the Trenton limestone of Wisconsin, which Hall seems to regard as very doubtfully allied to Graptolites, more closely resembles in general form the plants now under consideration, and may have been a'lied to them.

\section{CoRdaItes.}

C. Borassifolia, Corda, must be reckoned as one of the plants of this formation, though more abundant in the Millstone Grit and Middle Coalformation. At Horton there also occurs a narrow leaf, probably of this genus, and which seems to have been very long and parallel-sided. I have represented a fragment of it in Plate VI. Fig. 49.

Filices.

Cyclopteris (Aneimites) Acadica, Darson. Plate VII. Figs 53 to 63.-(Journal of Geological Society, Vol. XVII, P. 5.

Description.-Frond very large, the main stipe being sometimes three inches in diameter. Stipe finely and regularly striate, dichotomous several times, and finally loosely pinnate, each pinna having a long petiolule, and bearing a group of three

\footnotetext{
- Jahrback 1866.
} 
or more pinnæ which are flabellate and simple or divided into round lobes, with radiating and bifurcating veins. Fertile pinnæ with recurved petiolules, and borne on the divisions of the petiole near their origin. Form and arrangement of thecæ unknown.

This magnificent fern is eminently characteristic of the Lower Carboniferous Coal-measures. It is found in great abundance on the surface $s$ of shales at Horton, and has also been found at Norton Creek, New Brunswick, by Mr. Matthew, and in fragments at many other places. Its representative species in Eastern Europe is C. nana of Eichwald, and in the culm of Germany C. tenuifolia of Goeppert. It is probably an ally of C. obtusa of the Devonian.

There can be no doubt as to the manner in which its fructification was borne, in which respect it resembles the modern ferns of the genus Aneimia and also the Devonian ferns of the genus Archaeopteris; but unfortunately the precise form of its spore-cases is unknown.

In the mean time I adhere to my sub.genus Aneimites established in 1860*, and place with this plant A. obtusa, A. Bockshii and A. valida of the Devonian. For the reasons of this, and for a discussion of the affinities of these ferns, I refer to my Report on the Devonian and Silurian Plants, P. 48. In the plate, Figs 52, 53, 54, 55, show the stipe and its divisions. Figs 61,62 and 54 a, show the recurved petioles, on which the fructification was borne. Fig. 63 is a portion of a frond in vernation. Fgs. 56 to 60 show the pinnules and venation.

\section{Hrmenophyllites?-(Plate VII Figs. 64, 64 a.)}

Fragments of a fern which may belong to this genus have been found by Mr. Matthew at Sneid's Mill, Windsor, and are represented in the figure above referred to. They may, however, be fragments of petioles of a delicate frond of which the pinnules have perished through decay.

\section{Rhachiopteris.-(Plate VI, Figs. $47,48$.}

This is a peculiarly pitted fern-stipe which must belong to some fern different from the above and perhaps dotted with hairs or ramenta. It resembles the Devonian stipe which I have named $R$. punctata, and also the plant described by Eichwald under the name Schizopteris foveolata.

- Journ. Geol. S. Vol. XVII. 
Fruits, de.

\section{CARDIOCARPCM.}

Cardiocarpum tenellum S. N.-(Plate VI, Fig. 50, 50 a.)

Description.-Elongated oval, margin very narrow, a slight notch at the apex leading to a median furrow. Nucleus small, striated longitudinally, with traces of transverse strix.

This little fruit, which must for the present bo placed in the genus Cardiocarpum, is found scattered over the surfaces of shales at Horton, but not abundantly.

\section{Pinnularia.}

Pinnularia crassa, Dawson. Acadian Geology, P. 480.-(Plate VI, Fig. 51.)

The figure represents a portion of a slab covered with fragment of this plant from Horton. It was described in Acadian Geology as probably a root of Asterophyllites, but no species of that genus has yet been found in our Lower Carboniferous coal measures, and though probably a root, it remains uncertain to what plant it belonged. It differs from $P$. Capillacea in its coarser texture. 


\section{PLANTS OF THE MILLSTONE GRIT.}

\section{Coniferce.}

Dadoxylon (Paleoxilon) Acadiancm, Dawson.- (Cand. Nat. 1863. Journal of Geol. Society, 1866, Pl. V. Acadian Geology, P. 473.

I may refer to the rorks above cited for the description of this species, which is the characteristic fossil pine of the Millstone Grit and Middle Coal-formation, as $D$. materiarium is of the Upper Coal-formation. I have not yet found a Sternbergia pith in $D$. Acadianum; but loose Sternbergiæ, which may have belonged to it, sometimes occur in the sandstones of the Millstone Grit.

\section{Sigillarice.}

Both drifted and erect Sigillariæ occur in the middle division of the Millstone Grit at the South Joggins (Division 6 of Sir W. E. Logan's Section), but I have not any specimens sufficiently perfect for determination. Stigmariæ are not infrequent, and I have specimens of this genus from this horizon in several other parts of Nora Scotia and also in Newfoundland.

\section{Equisetacex.}

Plants of the genus Calamites are numerous in the Millstone Grit, and in this respect that formation agrees with the Upper Coal-formation, in which Calamites again become prevalent. The most abundant specimens in my collection belong to three forms, one of which I regard as identical with $C$. Cistii of Brongniart. Another is a broad-ribbed species which may belong to C. Steinhaueri or C. cannoformis, but is too imperfect for description. A third is represented by numerous and rery perfect speciməns, and is apparently C. undulatus of Brongniart. The two first require merely a passing notice. The last deserves more detailed consideration.

C.alanites Cistir, Brongt.-(Plate VII, Fig. 65.)

This species is found in the Millstone Grit; at Apple River; Riversdale; St. Mary's River; St. George's Bay. Newfoundland; \&c. It ranges from the Millstone Grit to the Upper Coal-formation. 
Calamites Canneformis, Brongt.

Specimens possibly referable to this species are found at Calvary River near Riversdale. It occurs in this horizon elsewhere, and also in the Devonian.

Calamites undulatus, Brongt. (Plate VII, Figs. 66 to 73. )

This species is stated by Brongniart to be distinguished from the C. Suckovii, the characteristic Calamite of the Middle Coal-formation, by its undulated ribs marked with peculiar cellular reticulation. $\mathrm{H}_{\theta}$ suggests that it may be merely a variety of $C$. Suckovii, an opinion in which Schimper coincides; but since I have received large additional collections from Mr. Elder, containing not only the stems and branches but also the leaves and rhizomes, I am constrained to regard it as a distinct though closely allied species. I shall endeavour to illustrate these points with the aid of the Figures in Plate VIII.

The rhizomata, Figs $73,73 \mathrm{a}, 73 \mathrm{~b}$, are slender, being from one to two inches in diameter and perfectly flattened. They are beautifully covered with a cellular reticulation on the thin bark, and show occasional round areoles marking the points of exit of the rootlets. I have long been familiar with irregular flattened stems thus reticulate, but have only recently been able to connect them with this species of Calamite.

The main stems, Figs. 66 to 68, present a very thin carbonaceous bark reticulated like the rhizomes. They have flat broad ribs separated by deep and narrow furrows, and undulated in a remarkable manner even when the stems are flattened. This undulation is, however, perhaps an indication of vertical pressure while the plant was living, as it seems to have had an unusually thin and feeble cortical layer, and the undulations are apparently best developed in the lower part of the stem. At the nodes the ribs are oftan narrowed and gathered together, especially in the vicinity of the rounded radiating marks which appear to indicate the points of insertion of the branches (Fig. 67). At the top of each rib we have the usual rounded areole probably marking the insertion of a primary branchlet (Figs. 68, 68 a.)

The Branches (Figs. 70, 71) have slender ribs and distant nodes, from which spring secondary branchlets in whorls, these bearing in turn small whorls of acicular leaflets much curved upward (Figs. 72, $72 \mathrm{a}, 72 \mathrm{~b}$ ), and which are apparently round in cross section and delicately striate They are much shorter than the leaves of Calamites Suckovii, and are less dense and less curved than those of $C$. nodosus, which I believe to be the two most closely allied species. 
Lesquereux notices this species as characteristic of the Lower part of the Carboniferous in Arkansas.

It will be observed that I regard the striated and ribbed stems not as internal axes, but as representing the outer surface of the plants. This was certainly the case with the present species and with C. Suckovii and C. nodosus. Other species, and especially those which belonged to Calamodendron, no doubt had a smooth or irregularly wrinkled external bark; but this gives no good ground for the manner in which some writers on this subject confound Calamites with Calamodendra, and both with Asterophyllites and Sphenophyllum. With this no one who has studied these plants, rooted in their native soils, and with their appendages still attached, can for a moment sympathize. One of the earliest geological studies of the writer was a bed of these erect Calamites, which he showed to Sir C. Lyell in 1844 and described in the Proceedings of the Geological Society in 1851, illustrating the habit of growth as actually seen well exposed in a sandstone cliff. Abundant opportunities of verifying the conclusions formed at that time have since occurred, the results of which have been summed up in the figures in Acadian Geology, which though they have becn treated by some botanists as merely restorations, are in reality representations of facts actually observed.

On these subjects, without entering into details, and referring for these to the elaborate discussions of Schimper, Williamson and $\mathrm{McNab}$, and to my paper on the subject, Journal of Greol. Society, vol. 27, p. 54, I may remark :-

1. That the aerial stems of ordinary Calamites had a thin cortical layer, with lacunæ and fibrous bundles and multiporous vessels-the whole not differing much from the structure of modern Equiseta.

2. Certain arborescent forms, perhaps allied to the true Calamites, as well as possibly the old underground stems of ordinary species $*$, assumed a thick-walled character in which the tissues resembled the wedges of an exogen, and abundance of pseudo-scalariform fibres were developed, while the ribbing of the external surface became obsolete or was replaced by a mere irregular wrinkling.

3. Sufficient discrimination has not been exercised in separating casts of the internal cavities of Calamites and Calamodendron from those representing other surfaces and the proper external surface.

4. There is no excuse for attributing to Calamites the foliage of Annularia, Asterophylites and Sphenophyllum, since these leaves have not been found attached to true Calamite stems, and since the structure of

-Williamson, Trans. Roy Socy. McNab in Proceedings of Edin. Botanical Society. 
the stems of Asterophyllites as rescribed by Williamson, and that of Sphenophyllum as described by the writer,, are essentially different from those of Calamites.

5. As the species above described indicates, good external characters can be found for establishing species of this genus, and these species are of value as marks of geological age.

\section{Lycopodiacece.}

Lepidodendron aculeatum, Sternberg.-(Plate IX, Figs. 75, 75 a, b, c.)

To this species I refer without much doubt the specimens from McKay's Head collected by Prof. Elder, one of which is represented in Fig. 75. This species, especially if, as Schimper supposes, identical with $L$. undulatum, ranges both in Europe and America through the whole extent of the Carboniferous system.

With the flattened stems of this Lepidodendron were found great quantities of the branches, leaves and cones represented in Figs. 77, 78, 80, and which in all probability belong to this or to the next species-probably to this; but as the leaves of $L$. aculeatum are not, I believe, known, I have no further evidence of this except their juxtaposition.

Lepidodendron radiato-Plicatum, S. N.-(Plate IX, Figs. 76, 76 a, b, c.)

Description.-Large stems with very elongate and acuminate rhombic leaf-bases having a strong central furrow and the leafscar a little above the centre, and trigonal in form with a single central vascular scar. The spaces between the leafbases marked with strong wrinkles radiating from the leafbases. Leaf-bases nearly 2 centimetres in extreme length and 5 millimetres in breadth.

This plant seems quite distinct from anything else I have met with, and is in very fine preservation, so that the characters can be made out distinctly. Being quite flattened, the denser tissues of the leaf-bases of the opposite sides have mutually impressed each other, so as to give a transversely tuberculated or ridged appearance as indicated in Fig. 76. The leaves more immediately associated with this species are the very elongate ones represented in Fig. 79.

Lepidodendron selaginoides, Sternberg.-(Pl. IX, Figs. 82, 83.)

This characteristic Lower Coal-formation species is found abundantly in connection with the Coal-beds of St. George's Bay, Newfoundland,

- Journal of Geol. Society, 1866. 
which I regard as in or near this horizon, and also in the lower part of the Middle Coal-formation or Upper Millstone Grit of Cape Breton.

Lepidophlotos Acadianus, Dawson.-(Plate IX, Fig. 85.)

A branch of this species occurs in the roof of a small coal at Salmon River, which must be near the upper limit of the Millstone Grit, and is the lowest geological position to which I have traced the specics.

CORdaites boRassifolia, Unger.-(Plate VIII, Fig 74.)

This species is very characteristic of the Millstone Grit and Middle Coal-formation in all parts of Nova Scotia and New Brunswick. I have represented in Fig. 74 a slab covered with its leaves, from Apple River.

\section{Filices.}

The ferns which I have obtained from the Millstone Grit are not very numerous, and. with one exception of species already fully described.

OdOnTOPteris ANTIQdA, Dawson.-(Plate $X$, Figs. 86, 87.) Tyclopteris antiqua, J. G. S. 1866, P. 154, Pl. XIII, F. 95. Acadian Geology, P. 481.

Description.-Tripinnate ; petioles slender ; pinnules oblong, obtuse, decurent on the petiole, not contiguous. Terminal pinnules much elongated; venation simple, divergent. This plant approaches more nearly to the peculiar species of Cyclopteris found in the Deronian, than any of the others I have seen in the Carboniferous.

The original specimens on which this species was founded were found on loose slabs at $R$. Hebert and Maccan River; but $I$ have since found fragments in situ at the Calvary River, near Riversdale. It seems to come within the technical characters of Odontopteris, but certainly approaches very nearly to some of the Devonian ferns of the genus Archoeopteris. Its fructification is needed to settle its true place.

ODONTOPTERIS ?-(Plate X, Fig. 88.)

A small fragment in Mr. Elder's collection from McKay's Head. Cardiopteris ?-(Plate X, Fig. 89.)

A few detached pinnules in Shale at Calvary River may indicate a species of this characteristic Lower Carboniferous genus. 
Alethopteris Lonchitica, Brongt (var, heterophylla.)-(Plate $X$, Fig. 90.)

The specimen figured was collected by the late Dr. Gesner at Moose River. The same species occurs in Mr. Elder's collections from McKay's Head; and as I have elsewhere shown it extends under different varietal forms through the whole of the Middle Coal-formation.

Pecopteris abbreviata, Brongt.-(Plate $X$, Fig. 91.)

The specimen figured is from the Coal above referred to at Salmon River, and appears to be a part of a frond of this common Coal-formation species.

Hymenophylites furcatus, Brongt. - (Plate $X$, Fig. 92.)

Collected at Calvary River.

Sphenopteris obtusiloba, Brongt.-(Plate $\mathrm{X}$, Fig, 93.)

Small fragments in Prof. Elder's collection from McKay's Head.

Spilisopteris Hoeninghausi, Brongt.-(Plate $X$, Fig. 94.)

Specimens having the characters of this species, though not well presorved, are in Prof. Bell's collections from St. George's Bay, Newfoundland. This species ranges from the Middle Devonian to the Millstone, Grit, and is one of the links connecting together the Devonian and Carboniferous Periods.

Paleopteris.-(Plate X., Fig. 95.)

A tree fern collected by Mr. Natthew at Gardiner's Creek, and which I was at first disposed to regard as a stem of Cordaites, but which seems to be a fern trunk nearly allied to my $P$. Acadica from the Upper Coalformation. 


\section{PLANTS OF THE MIDDLE AND UPPER COAL-FORMATION.}

These have already been illustrated in some detail in my memoir of 1866 already referred to, and in Acadian Geology; and though much new material has accumulated and many species have been inadequately figured, it may be some time before any full illustration of these plants can be attempted. For this reason, I give here a list of the species recognised in these groups of strata.

To avoid repetition of references, I may state that the new species established by Bunbury will be found in his papers in the Journal of the Geological Society, Vols. III and VIII. Those established by myself will be found in my paper in the same Journal, Vol. XXII, and my Acadian Geology, 2nd edition, 1868.

1. Middre Coal-formation, Nota Scotia and New Brensifick.

Dadoxylon Acadianum, Dawson.

- annulatum, Dawson.

Sigillaria (Farularia) elegans, Brongaiart.

- (Fav.) tessellata, Brongn.

- (Rh.) Schlotheimiana, Brongn.

- (Rh.) Saullii, Brongn.

- Brownii, Dawson.

- reniformis, Brongn.

- laevigata, Brongn.

catenoides, Dawson.

- striata, Dawson.

- (Clathraria) Menardi, Brongn.

- (Asolanus) Sydnensis, Dawson.

- organum, Lindley \& Hutton.

- elongata, Brongn.

- - flexuosa, L. \& H.

- pachyderma, L. \& H.

- (Far.) Bretonensis, Dawson.

- eminens, Dawson.

Dournaisii, Brongn.

Knorrii, Brongn.

Stigmaria ficoides, Brongn.

Antholites Rhabdocarpi, Dawson.

- pygmæa, Dawson.

Trigonocarpum Hookeri, Dawson.

- Sigillariæ, Dawson.

- intermedium, Dawson. a rellanum, Dawson.

- minus, Dawson. 


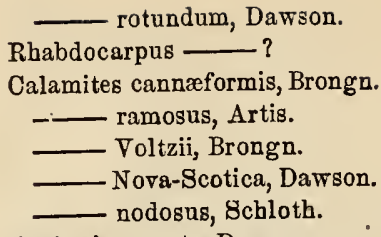

Equisetites curta, Dawson.

Asterophyllites foliosa, L. \& H.

- grandis? Sternberg, trinervis, Dawson.

Sphenophyllum emarginatum, Brongn. saxifragifolium, Sternberg.

Schlotheimii, Brongn. erosum, L. \& H.

Pinnularia capillacea, L. \& H. ramosissima, Dawson.

Noeggerathia dispar, Dawson. - fiabellata, L. \& H.

Cyclopteris (Neuropteris) obliqua, Brongn.

- (? Neuropteris) ingens, L. \& H. oblata, L. \& H.

- fimbriata, Lesquereux. hispida, Dawson.

Neuropteris rarinervis, Bunbury.

- perelegans, Dawson. Voltzii, Brongn.

- - flexuosa, Sternberg.

—— Loshii, Brongn.

- acutifolia, Brongn.

- conjugata, Goeppert.

- - attenuata, L. \& H.

- dentata, Lesq.

- Soretii (Brongn,)

cyclopteroides, Dawson.

Odontopteris subcuneata, Bunbury.

Dictyopteris obliqua, Bunbury.

Lonchopteris tenuis, Dawson.

Sphenopteris munda, Dawson.

—_ decipiens, Lesquereux.

- - gracilis, Brongn.

artemisiæfolia, Brongn.

Sphenopteris Canadensis, Dawson.

LLesquereuxii, Newberry.

microloba, Guttbier.

obturiloba (?), Brongn.

Phyllopteris antiqua, Dawson.

Alethopteris Grandini, Brongn.

— pteroides, Brongn.

Serlii, Brongn.

grandis, Dawson.

Pecopteris abbreviata, Brongn.

_- plumosa, Brongn.

polymorpha, Brongn. 


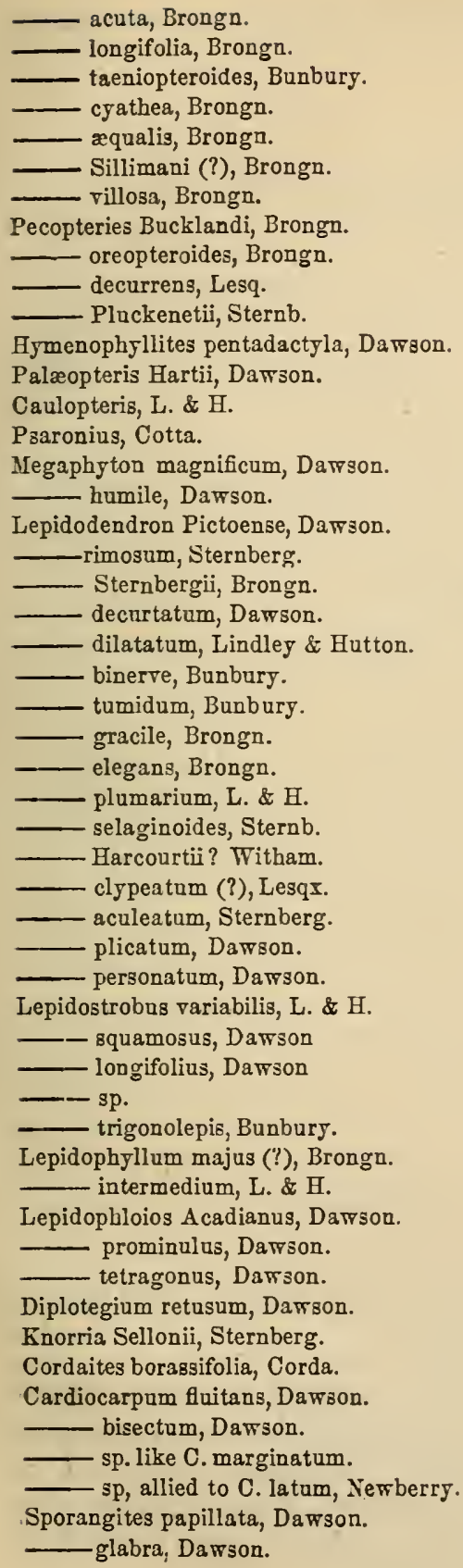


2 Upper Coal Formation, Nova Scotia, New Bronswick and Prince Edward Igland.

Dadoxylon matẹiarium, Dawson.

Walchia (Araucarites) gracilis, Dawson.

Walchia (Araucarites) robusta, Dawson.

Sigillaria (Rhytidolepis) scutellata, Brongn.

Calamodendron approximatum, Brongn.

Antholithes squamosa, Dawson.

Rhabdocarpus insignis, Dawson.

Trigonocarpum Noeggerathii, Brongn.

Calamites Suckorii, Brongn.

Cistii, Brongn.

- dubius, Artis.

- gigas, Brongt.

Asterophyllites equisetiformis, L. \& H.

Annularia sphenophylloides, Zeuker.

- longifolia, Brongn.

Sphenophyllum longifolium, Germar.

Cyclopteris heterophylla, Goeppert.

- oblongifolia, Goeppert.

Neuropteris cordata, Brongn. (and var. angustifolia).

- gigantea, Sternb.

- heterophylla, Brongn.

- auriculata, Brongn.

- rarinervis, Bunbury.

Udontopteris Schlotheimii, Brongn.

Sphenopteris hymenophylloides, Brongn.

- latior, Dawson.

Alethopteris lonchitica, Sternberg.

- nervosa, Brongn.

- muricata, Brongn.

Pecopteris arborescens, Schloth.

—_ rigida, Dawson.

- unita, Brongn.

oreopteroides (?), Brongn.

Beinertia Goepperti, Dawson.

Palæopteris Acadica, Dawson.

Lepidodendron undulatum, Sternberg.

Lepidophyllum lanceolatum, L. \& H.

- trinerve (?), L. \& H.

- $\mathrm{sp}$.

Lepidophloios parvus, Dawson.

Cordaites simplex, Dawson.

To this last list it is possible that a fer species may be added from my more recent collections in Pictou County.

Of the above species those which may be regarded as the most characteristic of the Newer Coal-formation, as distinguished from other members of the Carboniferous system, are perhaps Dadoxylon materiarium, the species of Walchia, Annularia sphenophylloides, Neuropteris auriculata, Peropteris arborescens, and Cordaites simplex. Calamites gigas is found only in the newest beds of the Upper Coal-formation. 


\section{V.-NOTE ON THE CHARACTERS OF SIGILLAROID AND LEPI- DODENDROID TRUNKS.}

From the loose manner in which plants of these groups are named and described by botanists, it seems useful to give some definitions of the parts employed in their determination.

It may be premised that the modes of determination in Fossil Botany are necessarily different from those employed in recent Botany. The Palreobotanist must have recourse to characters derived from the leaves, the scurs left by their fall, and the internal structures of the stem. These parts, held in little esteem by botanists in describing modern plants, and much neglected by them, must hold the first place in the regard of the fossil botanist, whereas the fructification, seldom preserved, and generally obscure, is of comparatively little service. It is to be remarked also that in such generalized plants as those of the Palæozoic, remarkable rather for the development of the vegetative than of the reproductive organs, the former rise in importance as compared with their value in the study of modern plants.

In Sigillarix, Lepidodendra, kc., the following surfaces of the stem may be presented to our inspection:-

1. The outer surface of the epidermis without its leaves, but with the leaf-bases and leaf-scars more or less perfectly preserved. On this surface we may recognize-(1) Cellular swellings or projections of the bark to which the leaves are attached. These may be called Leaf-bases, and they are sometimes very prominent. (2) The actual mark of the attachment of the leaf situated in the most prominent part of the leaf-base, This is the Leaf-scar. (3) In the leaf-scar when well preserved we can see one or more minute punctures or prominences which are the points where the vascular bundles passing to the leaf found exit. These are the Vascular scars.

When the leaves are attached, the leaf-scars and vascular scars cannot be seen, but the leaf-bases can be made out. Hence it is important, if possible, to secure specimens with and without the leaves. In flattened specimens the leaf-bases are often distorted by pressure and marked with furrows which must not be mistaken for true structural characters. The leaf-bases, which are in relief on the outer surface of the stem, of course appear as depressions on the mould in the containing rock, in which the markings often appear much more distinetly than on the plant itself. 
2. The outer surface of the epidermis may have been removed or may be destroyed by the coarseness of the containing rock. In this case the leaf-bases are usually preserved on the surface of the outer or corky bark, but the leaf-scars and vascular-scars have disappeared. This gives that condition of Lepidodendroid trees to which the name Knorria has been applied. When plants are in this state careful inspection may sometimes discover traces of the leaf-scars on portions of the stem, and thus enable the Knorria to be connected with the species to which it belongs.

3. The outer or corky bark may be remored, exposing the surface of the inner or fibrous and cellular bark, which in the plants in question is usually of great thickness. In this case neither the leaf-bases nor the scars are seen, but punctures or little furrows or ridges appear where the vascular bundles entered the inner bark. Specimens in this state are usually said to be decorticated, though only the outer bark is removed. It is often difficult to determine plants in this condition, unless some portion of the stem can be found still retaining the bark; but when care is taken in collecting, it will not infrequently be found that the true outer surface can be recovered from the containing rock, especially if a coaly layer representing the outer bark intervenes between this and the inner impression. Specimens of this kind taken alone, have been referred to the genera Knorria, Bothrodendron and Halonia.

4. In some cases, though not frequently, the outer surface of the ligneous cylinder is preserved. It almost invariably presents a regularly striated or irregularly wrinkled appearance, depending upon the vertical woody wedges, or the positions of the medullary rays or vascular bundles. Specimens of this kind constituted some of the Endogenites of the older Botanists, and the genus Schizodendron of Eichwald appears to include some of them. Many of them have also been incorrectly referred to Calamites.

5. In some cases the cast of the medullary cylinder or pith may alone be preserved. This may be nearly smooth or slightly marked by vertical strix, but more usually presents a transverse striation, and not infrequently the transverse constrictions and septa characteristic of the genus Sternbergia. Loose Sternbergiæ afford little means of connecting them with the species to which they belong, except by the microscopic examination of the shreds of the ligneous cylinder which often cling to them.

These facts being premised, the following general statements may be made respecting some of the more common Palæozoic genera, referring, however, principally to the perfect markings as seen on the epidermis.

- See my paper, Journal of Geol. Society, Vol. XXVII. 
Sigillaria.-Leaf-bases hexagonal or elongated, or confluent on a vertical ridge. Leaf-scars hexagonal or shield-shaped. Vascular scars three, the two lateral larger than the central. This last character is constant, depending on the fact that the leaves of Sigillaria have two or more vascular bundles. All so-called Sigillariæ having the central vascular scar largest, or only one vascular bundle, should be rejected from this genus. In young branches of branching Sigillarix the leaf-scars sometimes appear to be spiral, but in the older stems they form vertical rows ; interrupted, however, by transverse rows or bands of Fruit-scars, each with a single large central vascular scar, and which have borne the organs of fructifcation. Arthrocaulis of $\mathrm{McC}$ y is founded on this peculiarity. Syringodendron.-Differs from Sigillaria in the leaf-scars, which are circular and with a single vascular bundle. It is a matter of doubt whether these plants were of higher rank than Sigillaria tending toward the pines, or of lower rank tending toward Cyclostigma. Their leaf-bases form vertical ridges.

Lepidodendron.--Leaf-bases rhombic, oval or lanceolate, moderately prominent. Leaf-scars rhombic or sometimes shieldshaped or heart-shaped, in the middle or upper part of the leaf-base. Vascular scars three-the middle one always largest and corresponding to the single nerve of the leaf; the lateral ones sometimes obsolete.

In older stems three modes of growth are observed. In some species the expansion of the bark obliterates the leaf-bases and causes the leaf-scars to appear separated by wide spaces of more or less wrinkled bark, which at length becomes longitudinally furrowed and simulates the ribbed character of Sigillaria. In others the leaf-bases grow in size as the trunk expands, so that even in large trunks they are contiguous though much larger than those on the branches. In others the outer bark, hardening at an early age, is incapable of either of the above changes, and merely becomes cleft into deep furrows in the old trunks.

Lepidophloios.-Leaf-bases transverse and prominent-often very much so. Leaf-scars transversely rhombic or oral with three vascular scars, the central largest. Leaves very long and one-nerved. Large strobiles or branchlets borne in two ranks or spirally on the sides of the stem, and leaving 
large round scars (Conc-scars) often with radiating impressions of the basal row of scales.

Species with long or drooping leaf-bases have been included in Lepidophloios and Lomatophloios. Species with short leaf bases and cone-scars in two rows have been called Ulodendron and some of them have been included in Sigillaria (sub-genus Clathraria). Decorticated stems are Bothrodendron and Halonia. Some of the species approach near to the last genus, especially to the Lepidodendra with rhombic leaf-bases like L. tetragonum.

Cyclostigma.-Leaf-bases undeveloped. Leaf-scars circular or horse-shoe shaped, small, with a central vascular scar. In old trunks of Cyclostigma the leaf-scars become widely separated, and sometimes appear in rertical rows. Young branches of Lepidodendron sometimes hare the leaf-scars similar to those of Cyclostigma.

Leptophleum.-Leaf-bases flat, rhombic; leaf-scars obsolete; vascular scar single, central. The tro last genera are characteristically Devonian.

In contradistinction from the trees above mentioned, the following general statements may be made respecting other groups.

In Conifers the leaf-bases are usually elongated vertically, often scaly in appearance, and with the leaf-scar terminal and round, oval or rhombic, and with a single well-marked vascular scar.

In Calamites, Calamodendron and Asterophyllites the scars of the branchlets or leaves are circular or oval with only a single vascular scar, and situated in verticils at the top of well-marked nodes of the stem.

In Tree-ferns the leaf-bases are large and usually without a distinct articulating surface. The vascular. bundles are numerous. Protopteris has rounded leaf-scars with a large horse-shoe shaped bundle of vessels above and small bundles below. Caulopteris has large elliptic or oval §leaf scars with vascular scars disposed concentrically. Palæopteris* of Geinitz has the leaf-scars transversely oval and the vascular bundles confluent in a transverse band with an appendage or outlying bundle below. Stemmatopteris has leaf-scars similar to those of Caulopteris, but the vascular bundles united into a horse-shoe shaped band.

*This name, preoccupied by Geinitz, has been inadvertently misapplied to the Devonian ferns of the genus Archæopteris. 


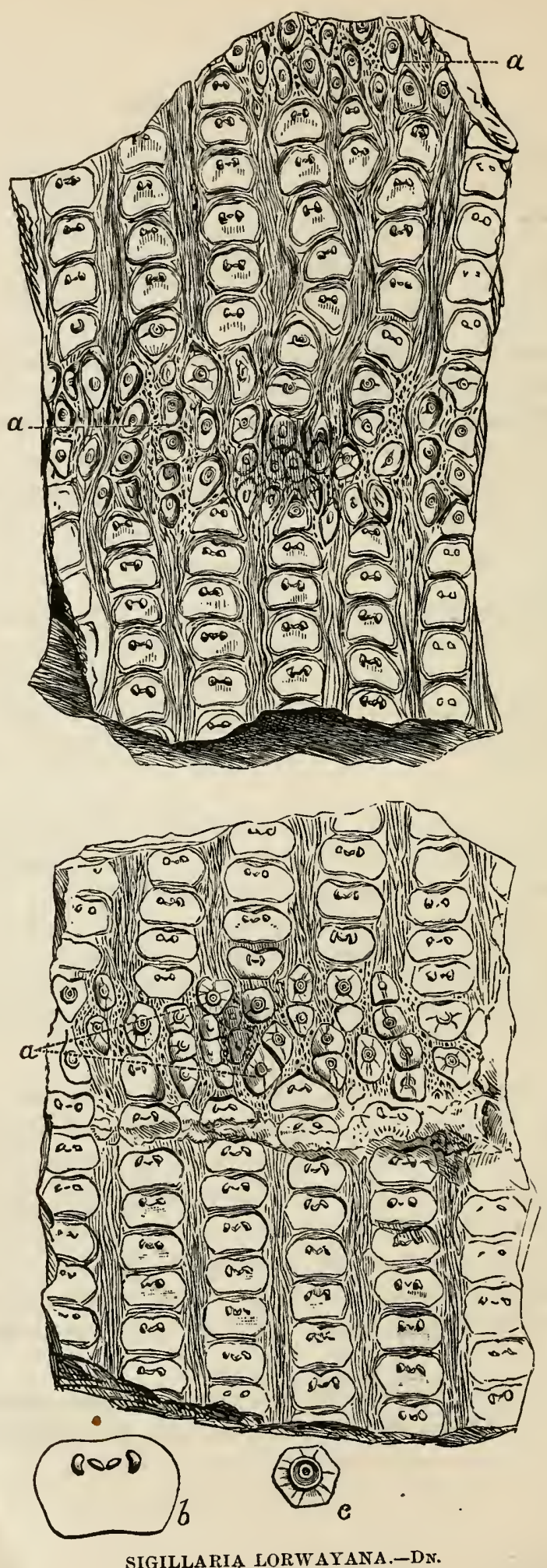

SIGILLARIA LORWAYANA.-DN.

Zones of Fruit-scars at $(a, a, a) . \quad(b)$ Leaf-scar enlarged. $\quad$ (c) Fruit-scar cnlarged. 


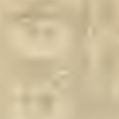

\section{VI-APPENDIX.-ON SOME NEW FORYS OF SIGILLARIA AND LEPIDODENDRON.}

While the above Report was in progress, some interesting specimens have been received from Mr. Hill, of the Emery Mine, Cape Breton, and which throw light on some obscure forms of the Middle Coal formation previously known, but not well understood. As these are of some interest, I give a preliminary notice of them herc, though they deserve to be fully figured and described.

\section{1.-Sigillaria Lorwayana, S.N. *}

This has long been known to me by specimens from Sydney in the collection of Mr. R. Brown, but I did not feel justified in describing it as new. It is a very beautiful form of that type in which the leaf-bases are very large and contiguous to each other, and its nearest allies are my $S$. Bretonensis and Schimper's $S$. Lalayana. Its description is as follorrs :-

Leaf-bases about $8 \mathrm{~m} . \mathrm{m}$. broad and $5 \mathrm{~m} . \mathrm{m}$. high, in trunks of moderate size, hexagonal with rounded angles, or approaching to oblong, sometimes a slight indentation below causes them to appear reniform. They are contiguous or nearly so in vertical roms, being separated from each other only by a slight ridge. The rows are separated by spaces of mrinkled bark nearly half as mide as the leaf-bases. Vascular scars near the top of the leaf-base, each having tro minute and often confluent points and two larger and lunate lateral punctures.

Fruit-scars arranged in transverse rows forming a girdle, each member of the girdle consisting of 2 to 7 contiguous vertical scars placed in the spaces between the leaf-scars in the vicinity of an articulation, where the rows of leaf-scars are not continuous, as if there har been an interruption of growth. These articulations are from two inches to a foot apart vertically. The scars are depressed or sunk into the stem, rounded or angular by pressure, and haring in the centre a small sunken ring and dot.

The bark appears to bave been thin. Flattened specimens are sometimes a foot in diameter.

When the epidermis is removed, the inner surface appears rugose longitudinally, and there are transverse leaf-scars, each with two vascular points, the whole presenting the appearance of the type Leioderma.

- Named from the "Lorway" Coal seam, near which it is found. 
The fruit-scars are evidently modified leaf-scars passing into these. They have thus no affinity either in form or relation with the large round cone-bearing-scars of Lepidofloios, and they must either have borne single ovules or modified leaves with marginal fruit. In the former case the shape of the base would indicate that the fruits were of the nature of Trigonocarpa. In the latter case they were probably of the nature of Antholites, (which are not, as Carruthers supposes, to be confounded with Cardiocarpa.) Or they may have been racemes of Trigonocarpa, as I suggested many years ago.* Still it is possible that some of the plants included in Sigillaria may have borne Cardiocarpa, and the mode of association of these in racemes, as shown by Carruthers in one of the species, is a further evidence of this possibility.

In any case it is perfectly plain both from considerations of homology and from the form and close approximation of the fruit-scars, that they could not have borne strobiles of the nature of those figured by Goldenburg and Schimper as fruits of Sigillaria.

Some of the trunks are imbedded in what seem to be masses of flattened fern stipes, but which might be readily mistaken for leaves, and the stems of this and the next species are not unfrequently filled or interlaced on the surface with rootlets of Stigmaria belonging to succeeding geverations of trees.

\section{2.-Clathraria Menardi, Rrongt.}

I have elsewhere discussed the probable affinities of those Sigillarix which have rhombic or elliptical leaf-bases arranged spirally, and which in this respect resemble Lepidofloios, to which, I have no.doubt, somo of the species belong; but which, as I have elsewhere shown, also resemble the young branches of Sigillarixe of the type of $S$. elegans. $\dagger$

In Mr. Hill's collection there are some very instructive specimens of this type from the Reserve Coal Mine. They have transversely elliptic and acuminate leaf-bases about 5 m.m. broad, and similar, but for the large size, to those of $S$. Menardi of which they may represent a luxuriant variety. The leaf-scars are small protuberances above the centre of the base and each with two vascular punctures. The surface under the epidermis is longitudinally striate, and the scars appear as single punctures arranged in quincunx, and giving the plant at first sight the appearance of a Stigmaria with very small and distant areoles.

- Acadian Geology p. 437, 438 and 459.

† Acadian Geology p. 435. 
The plant evidently branched dichotomously. Its appearance was that of very young branches of $S$. elegans magnified in dimensions. Old decorticated trunks might readily be referred to the sub-genus Leioderma, as presenting merely a wrinkled surface without ribs or leaf-bases.

In one specimen the exogenous manner of the growth is well seen in the overlapping of the bark in a ridge at the junction of the branches.

\section{3.-Lepidodendron Sternbergii and its allies.}

The descriptions of this species in the books are of such a nature as to give rise to the suspicion that in addition to the $L$. longifolium which Schimper has separated, other species may be included under the name.

In Mr. Hill's collection, and also in Mr. R. Brown's, and among plants received some years ago from Mr. H. Poole, all from the Middle Coal-formation of Cape Breton, there are specimens which differ so markedly from the ordinary $L$. Sternbergii that I must regard them as a distinct species or at least varietal form. They may be described thus :-

Leaf-bases in old trunks broadly oval, acuminate at both ends, about 6 m.m. long and 4 m.m. broad, separated from each other by a border of wrinkled epidermis. Leaf-scars transversely rhombic with three small subequal vascular points below the middle, and a tubercle at the apex.

In young trunks the leaf-bases become shorter and contiguous, and in this state resemble those of young branches of $L$. Sternbergii and $L$. decurtatum, though in good specimens distinguishable. The leaves are narrow and as much as 5 inches long, one-nerved, though appearing two nerved" near the base.

Certain remarkable leafy strobiles with bracts three or four inches long, Lepidostrobus longifolius, are probably referable to this species or to $L$. decurtatum.

In the present species or variety the branches are very spreading, or given off at very obtuse angles. Hence, if a distinct species, I would name it $L$. dispansum. 


\section{EXPLANATION OF THE PLATES.}

\section{(Lower Carboniferous).}

Plate I. Dadoxylon, \&c.

Fig. 1. Dadoxylon antiquius,-Longitudinal section, tangential.

2. —— Longitudinal section, radial.

3. —— Transverse section.

4 and 5.-_- Discs and pores.

6. Fragment of wood of Sigillaria, 6 a, 6 b, portions of fibres.

7 and 8.- Lycopodites plumula.

9. —— portion enlarged.

Plate II. Lepidodendron corrugatum.

Fig. 10. End of branch with young strobile.

11, 12. Branches with leaves.

13, 14, 15. Branches with leaf-bases, (a) enlarged.

16 to 20. Portions of old stems, showing leaf bases separated by wrinkled bark, (a) enlarged.

21. Very old stem decorticated.

22. Spore cases, natural size, and (a) enlarged.

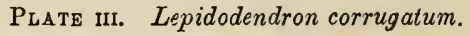

Fig. 23. Leafy brancb, 23 (a), (b), (c). Leaves natural size and enlarged.

24. Decorticated branch-(Knorria).

25. Branch with leaves.

26 to 28 . Various decorticated Knorriæ, (a) markings enlarged.

29. Bark showing vertical ribs, (a) rib enlarged.

PLATE IV. Roots of Lepidodendron, \&c.

Fig. 30. Extremity of a flattened branch of Stigmaria, showing areoles and rootlets, $30 \mathrm{a}, \mathrm{b}$, areole enlarged and rootlet showing mark of vascular bundle.

31. Stigmaria, (a) areoles.

32. Portion of an erect stem of Lepidodendron corrugatum, from near the base.

Plate v. Lepidodendra.

Fig. 33 to 35. Lepidodendron corrugatum,-Variety Cyclostigmoides-young branch and portions of old stems, (a) scars enlarged.

36. Variety with scars in vertical rows on ribs, 36 a, portion enlarged.

37. Lepidodendron aculeatum, (a) single leaf-base.

38. Lepidodendron, probably corrugatum, showing marking of inner surface of bark.

39. Lepidodendra tetragonum, (a) areole enlarged.

40. Portion of strobile with scales removed, (a) scar enlarged

Plate vi. Lepidodendra, \&c.

Fig. 41. Fragment of Strobile, (a) scales detached.

42, 43. Lepidodendron Sternbergii, branches, (a) scar and leaf-base enlarged.

44, 45. Branches showing leaf-bases, (a) leaf-base enlarged

46. Diplotegium, (a) leaf-base enlarged.

47, 48. Stipe of Fern (Rhachiopteris).

49. Cordaites, (a) venation enlarged.

50. Cardiocarpum tenellum.

51. Pinnularia crassa. 
Plate vil. Cyclopteris Acadica, \&c.

52, 53,54. Stipes of Cyclopteris Acadica ; (a) attachment of fructification, 54 a, striation enlarged.

55 to 60 . Pinnules of the same.

61 to 63 . Remains of fructification of the same.

64. Hymenophyllites? (a) fragment enlarged

(Millstone Grit).

Phate virI. Calamites, $\& c$.

Fig. 65. Calamites Cistii.

66 to 68 . Calamites undulatus,-Portions of stem, showing ribs, nodes and attachments of branches and branchlets; 68 (a) markings enlarged.

69 to 71 . Branches of the same, showing attachments of brauchlets, 70 a, porticn $\in n$ larged

72. Branchlet and leaves; 72 a and $b$, portions enlarged.

73. Fragment of Rhizoma of the same; 73 a and b, markings enlarged.

74. Slab with Cordaites borassifolia.

Plate ix. Lepidodendra, $\$ c$.

Fig. "15. Lepidodendron aculeatum; 75 a, inner surface of bark, 75 b, c, leaf-bases and leafscars

76. Lepidodendron radzato-plicatum; $76 \mathrm{a}, \mathrm{b}$, c, leaf-bases, leaf-scar and vascular-scar.

77. Branch (fertile) of Lepidodendron.

78. Fragments of Strobiles; (a) scale, (b) group of scales, (c) axis.

79 to 81 . Leares and cone-scales of the same.

82. Lepidodendron Selaginoides; (a) leaf-base enlarged.

83. Branches and leaves of the same.

84. Old decorticated stem of the same.

85. Lepidofloios Acadianus, fragment of stem; (n) scar of cone.

Platex. Filices.

Fig. 86, 87. Odontopteris antiqua.

88. Odontopteris, sp.

89. Cardiopteris.

90. Alethopteris lonchitica.

91. Pecopteris abbreviata.

92. Hymenophyllites furcatus; (a) portion enlarged.

93. Sphenopteris obtusiloba.

94. Sphenopteris Hoeninghausi; (a) portion enlarged.

95. Palsopteris. 


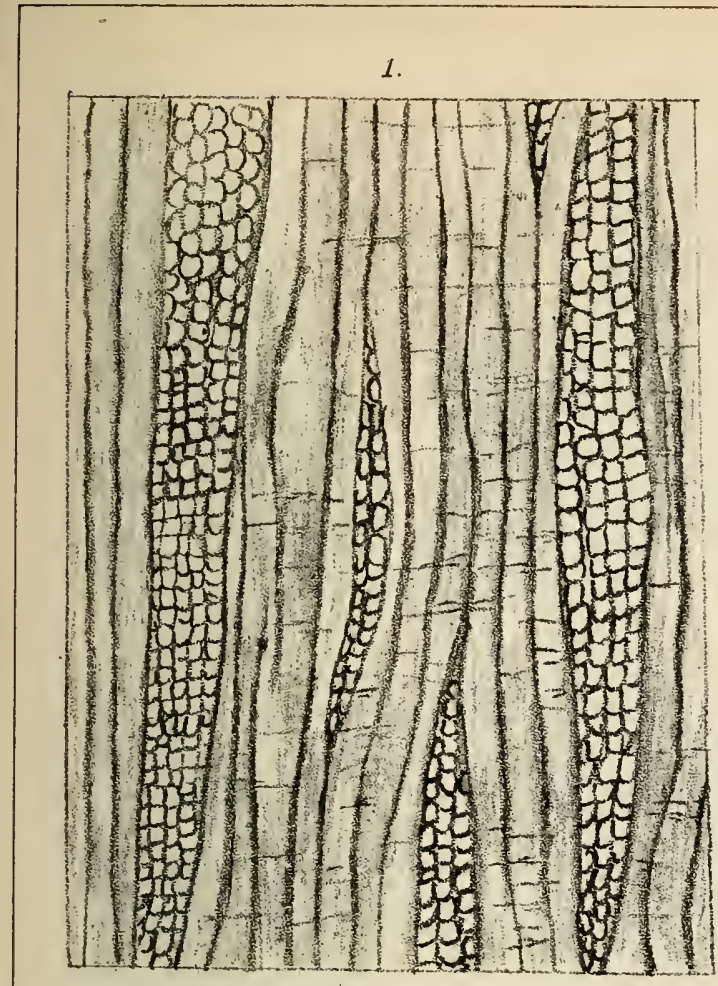

2.

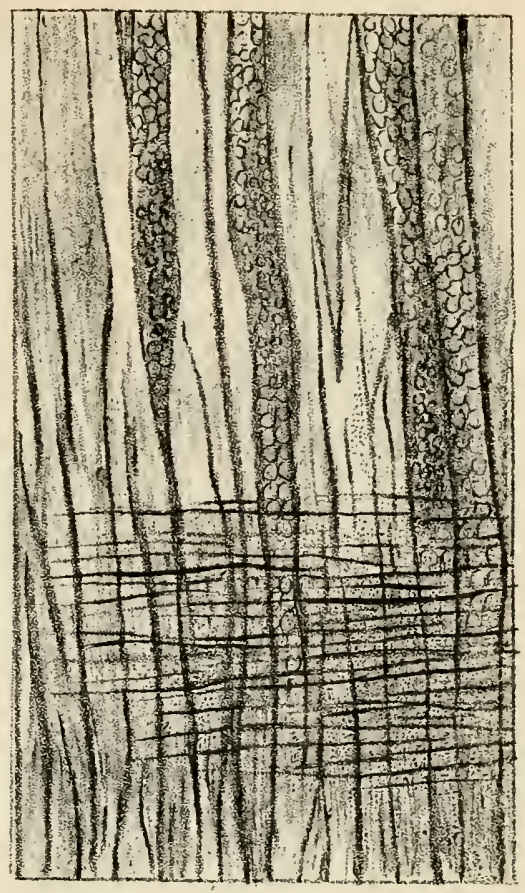

$x$ (n)r).
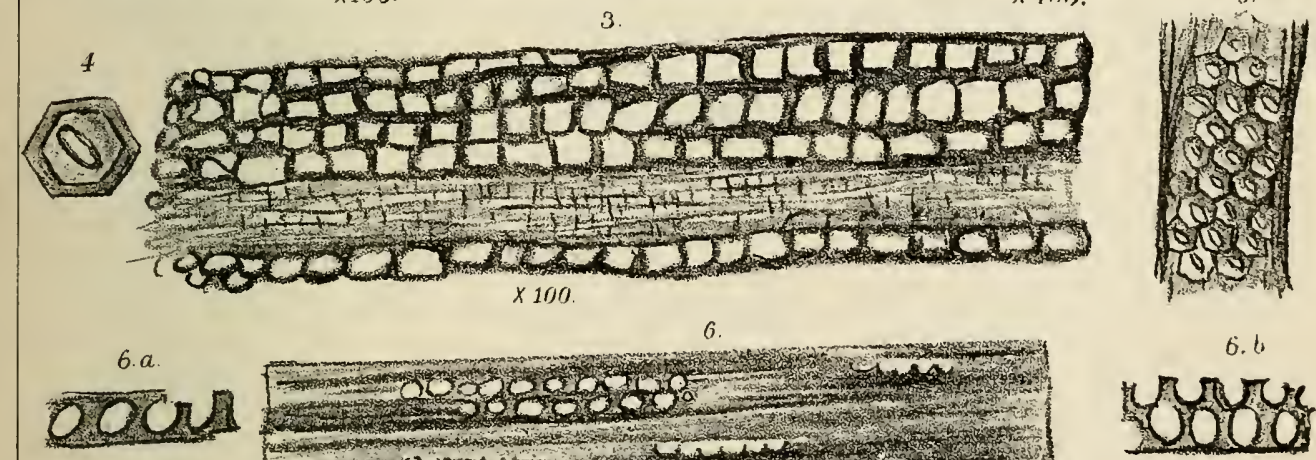

6

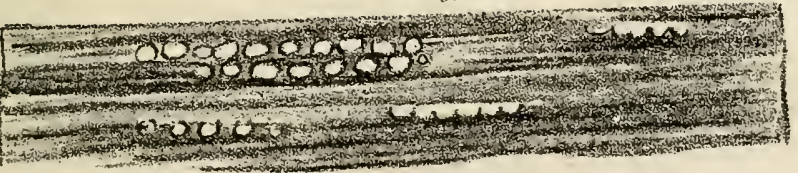

noores
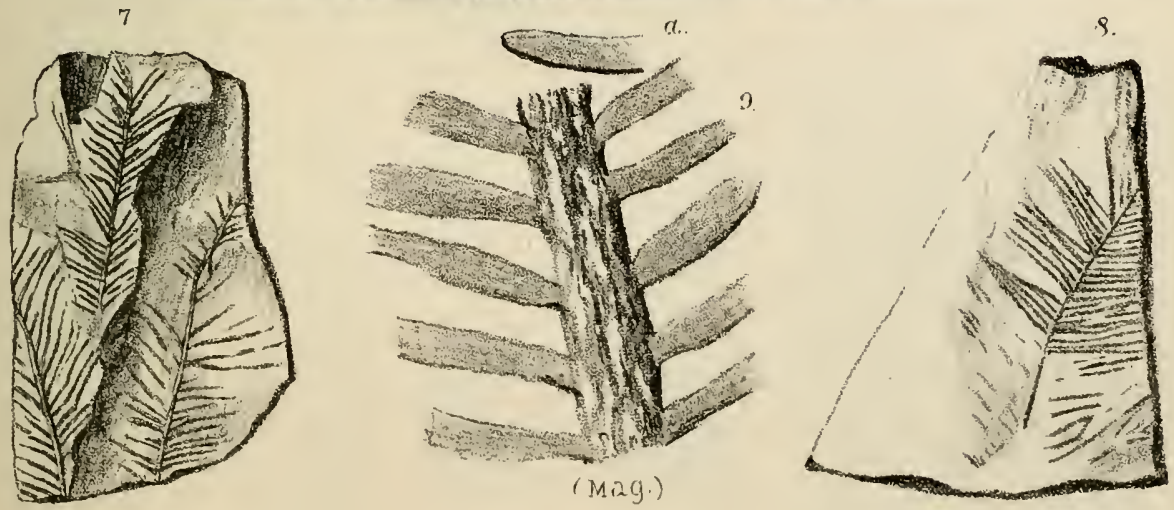

DADOXYLON \&C - LOWER CARBONIFEROUS. 

Geological Survey of Canada.

Plate II.

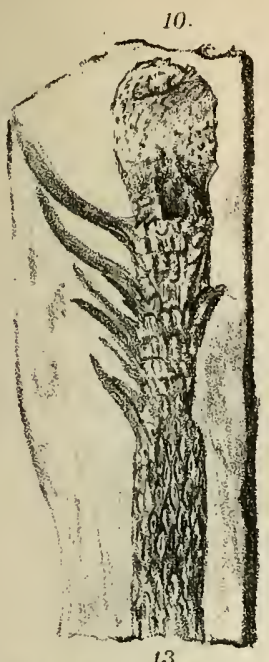

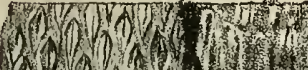

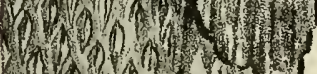
ny now

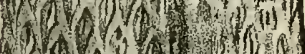

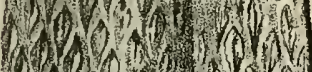

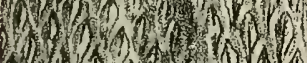

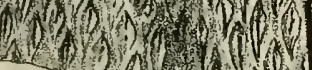

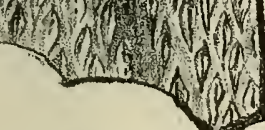

17

I) $\left.{ }^{10}, 0\right)$ (1) J (1) homonan Haghan 1) $10 \mathrm{~m}$ 1100 20.

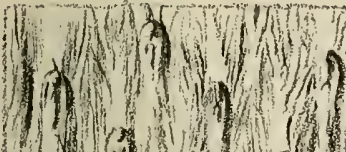
1) 3 (n) How Hol 13 (1) (1) (n) 1) (1) Don H) Wh

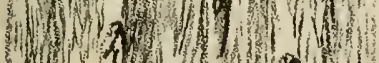
Hor Jum

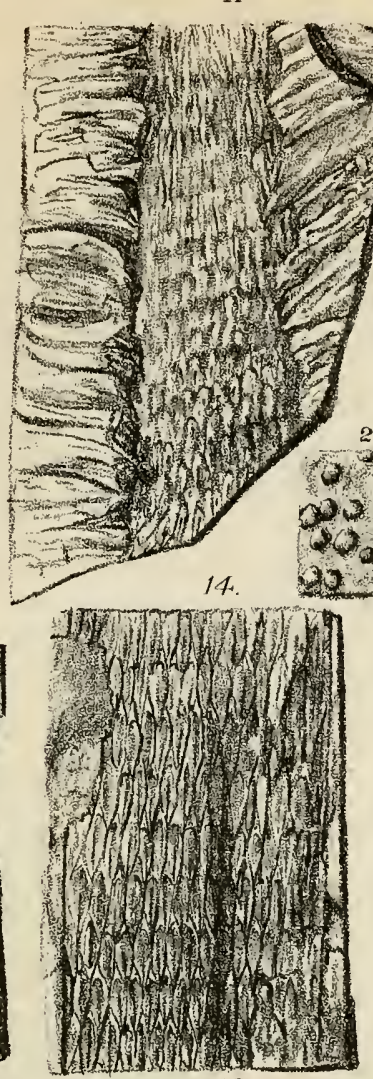

12.
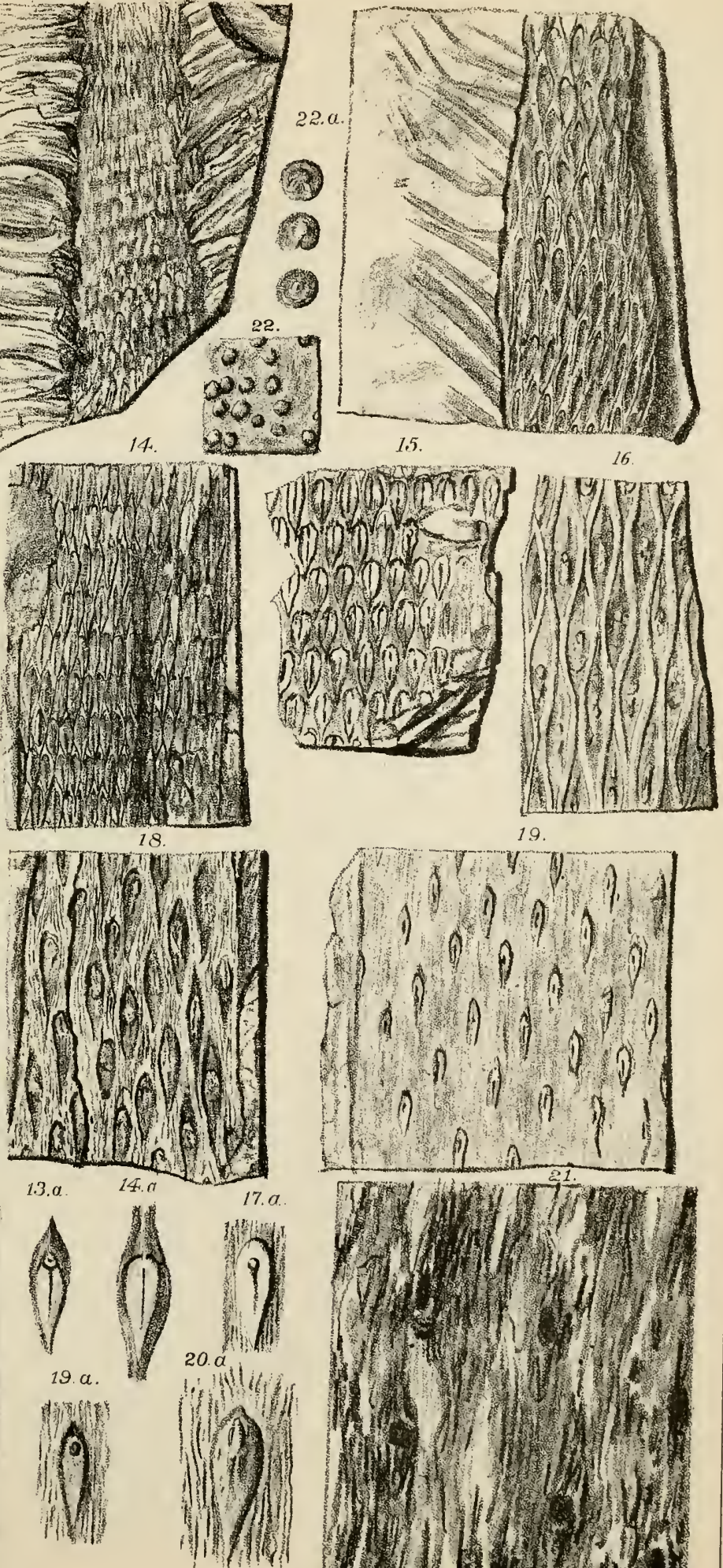

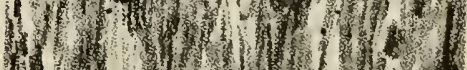

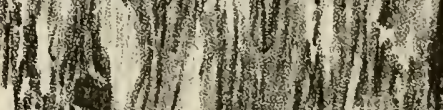

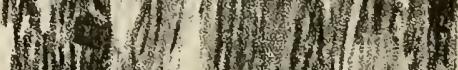

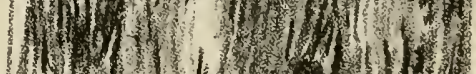
Whollown

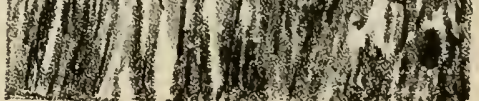





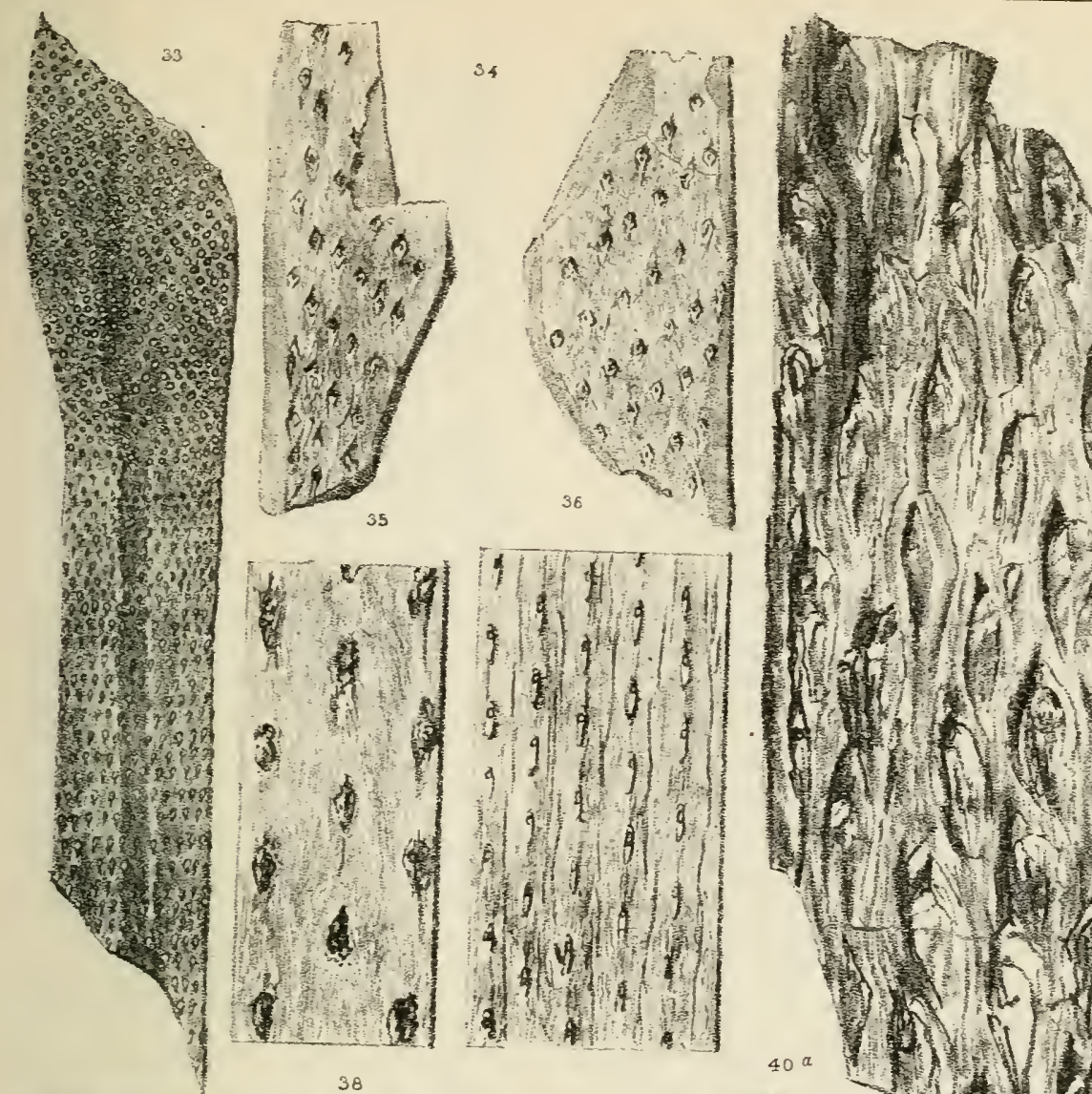

Whoth

h)

Whon In)

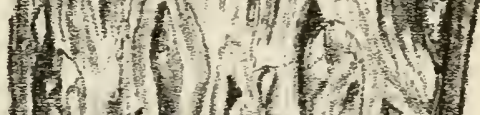

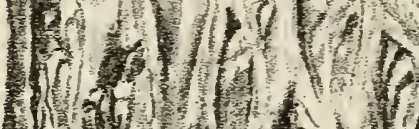
(n) Hom Whand Why (1) (n)

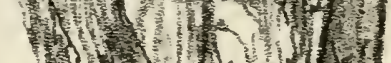
Wh
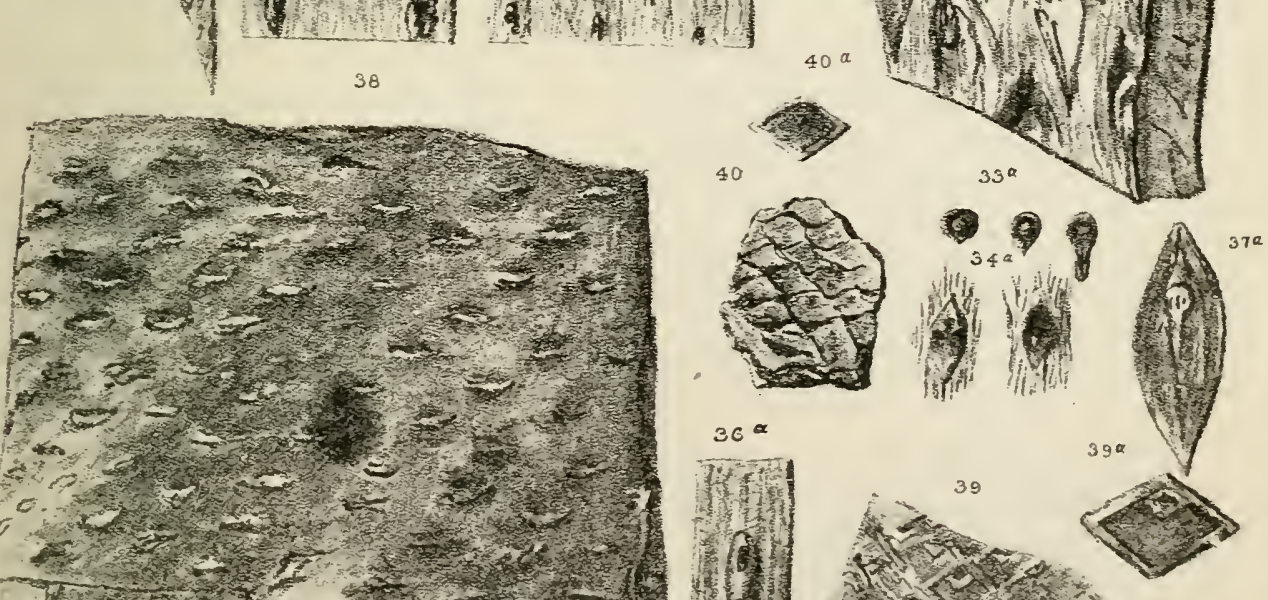

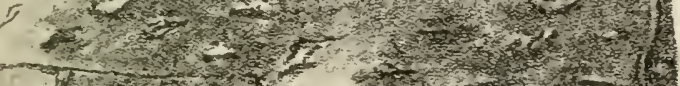

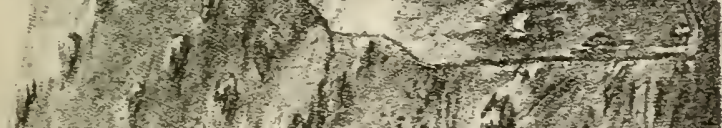

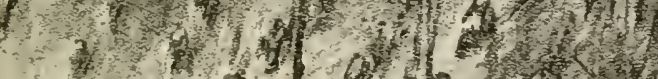

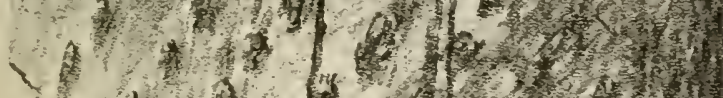

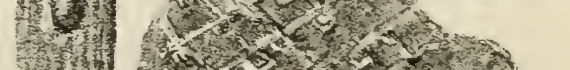

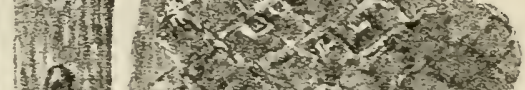

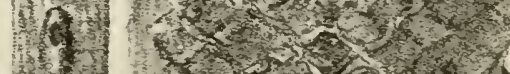
mus

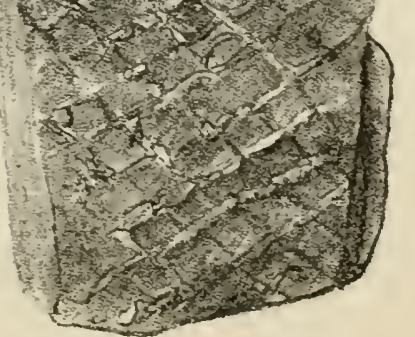
id 



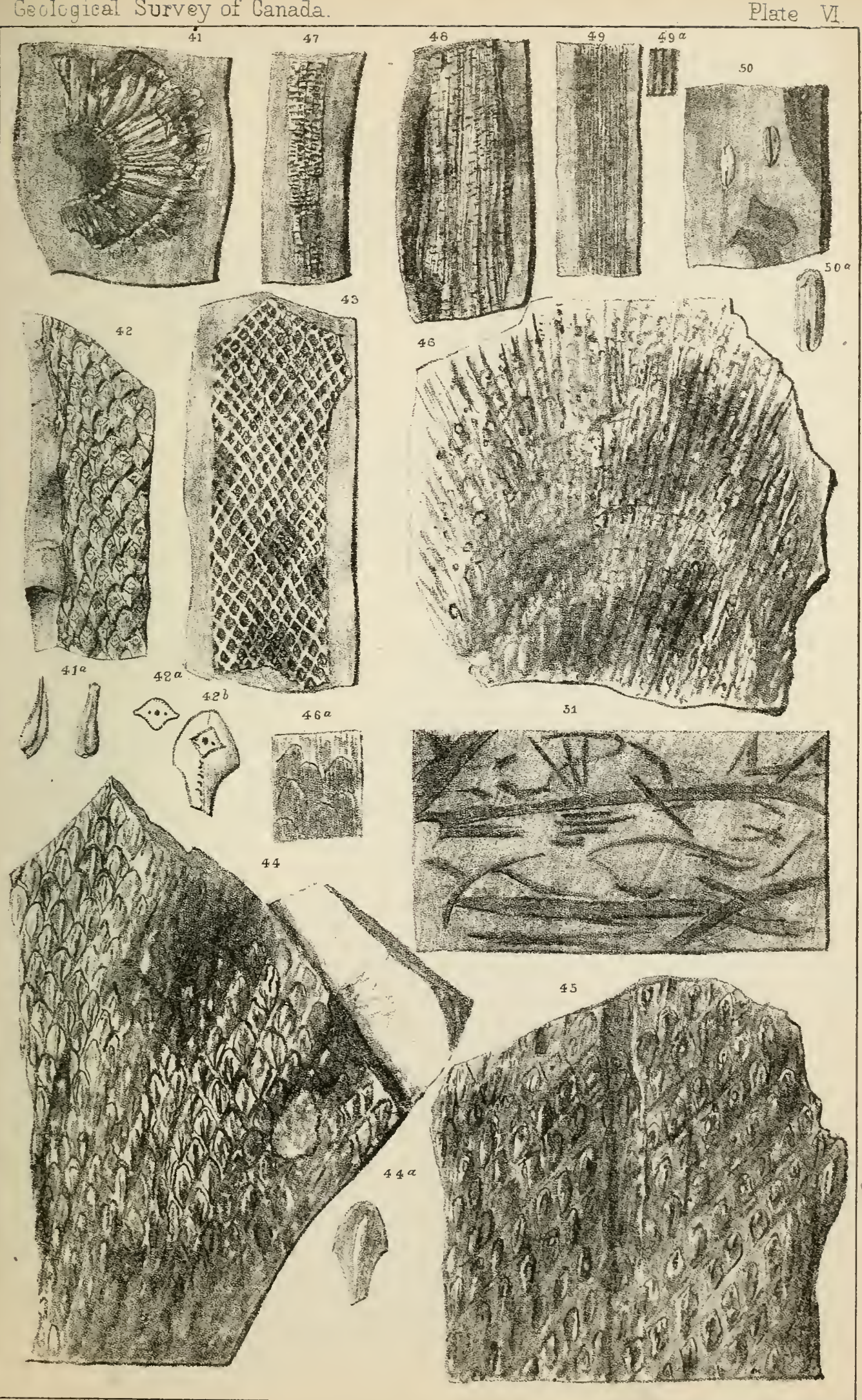





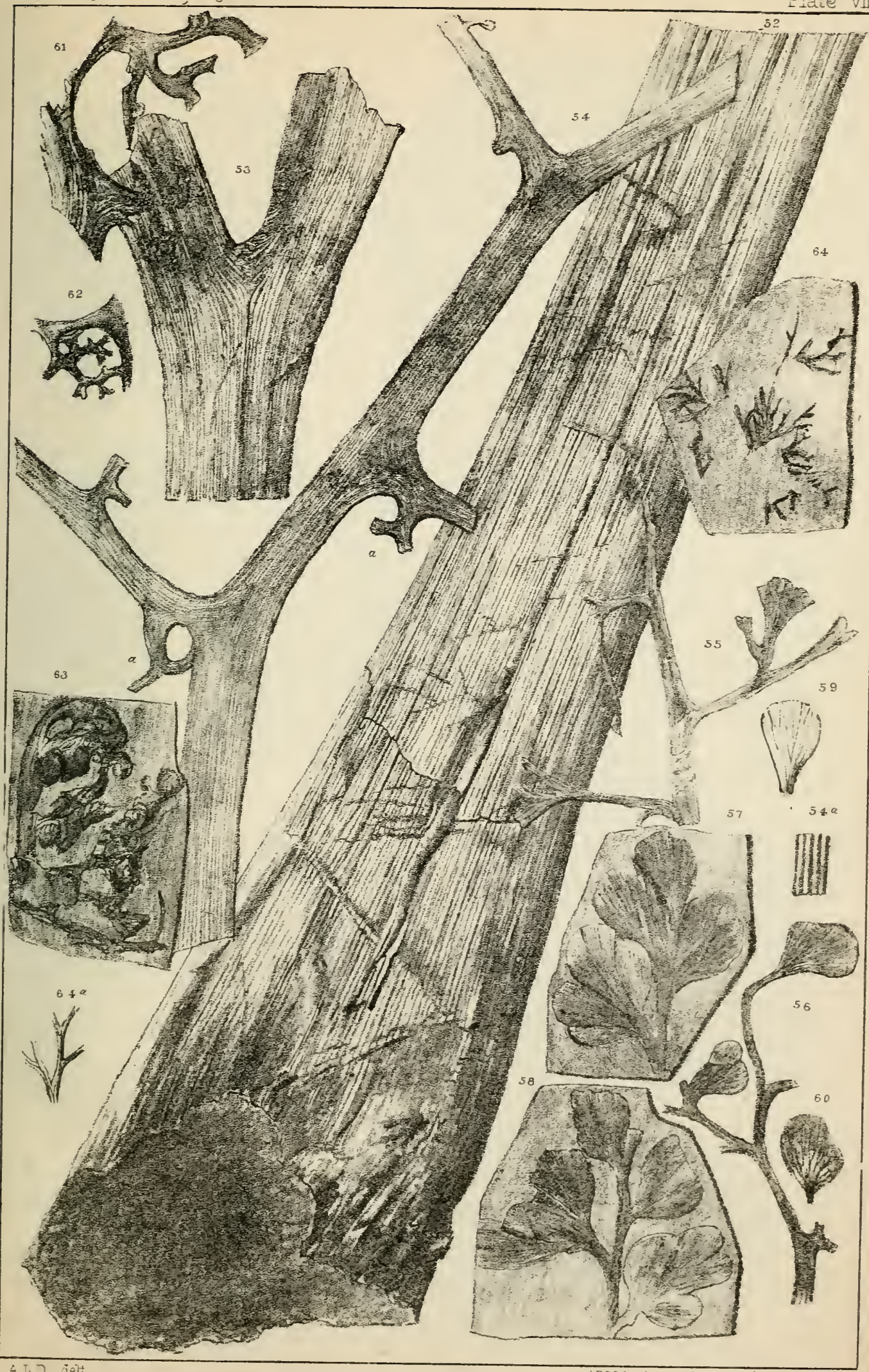






66
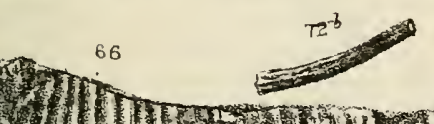

(1) (1) (1),

3. $4(1) \cdot(1)=$

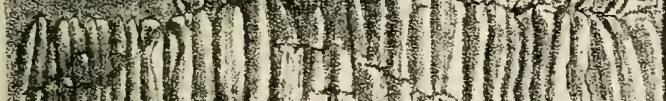
(6) (17m

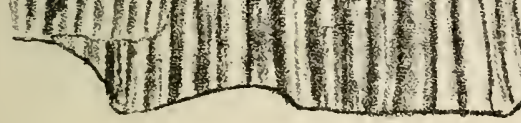
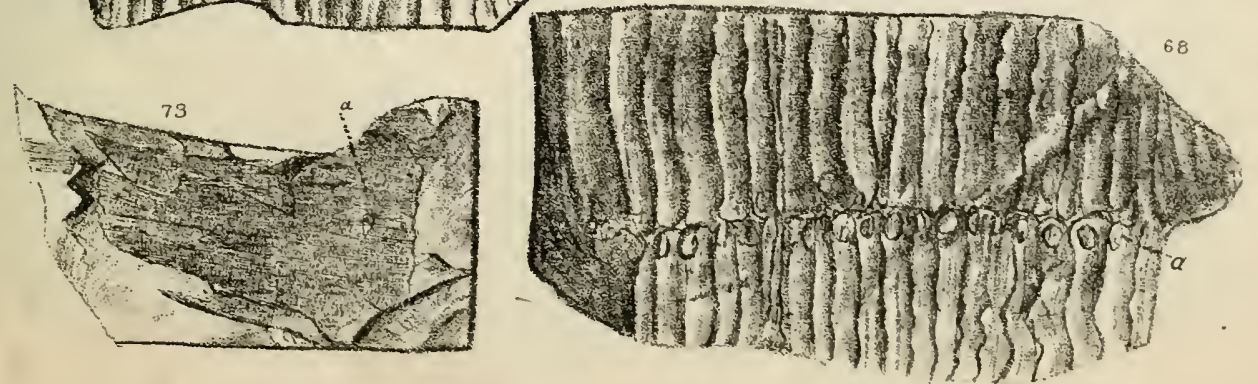


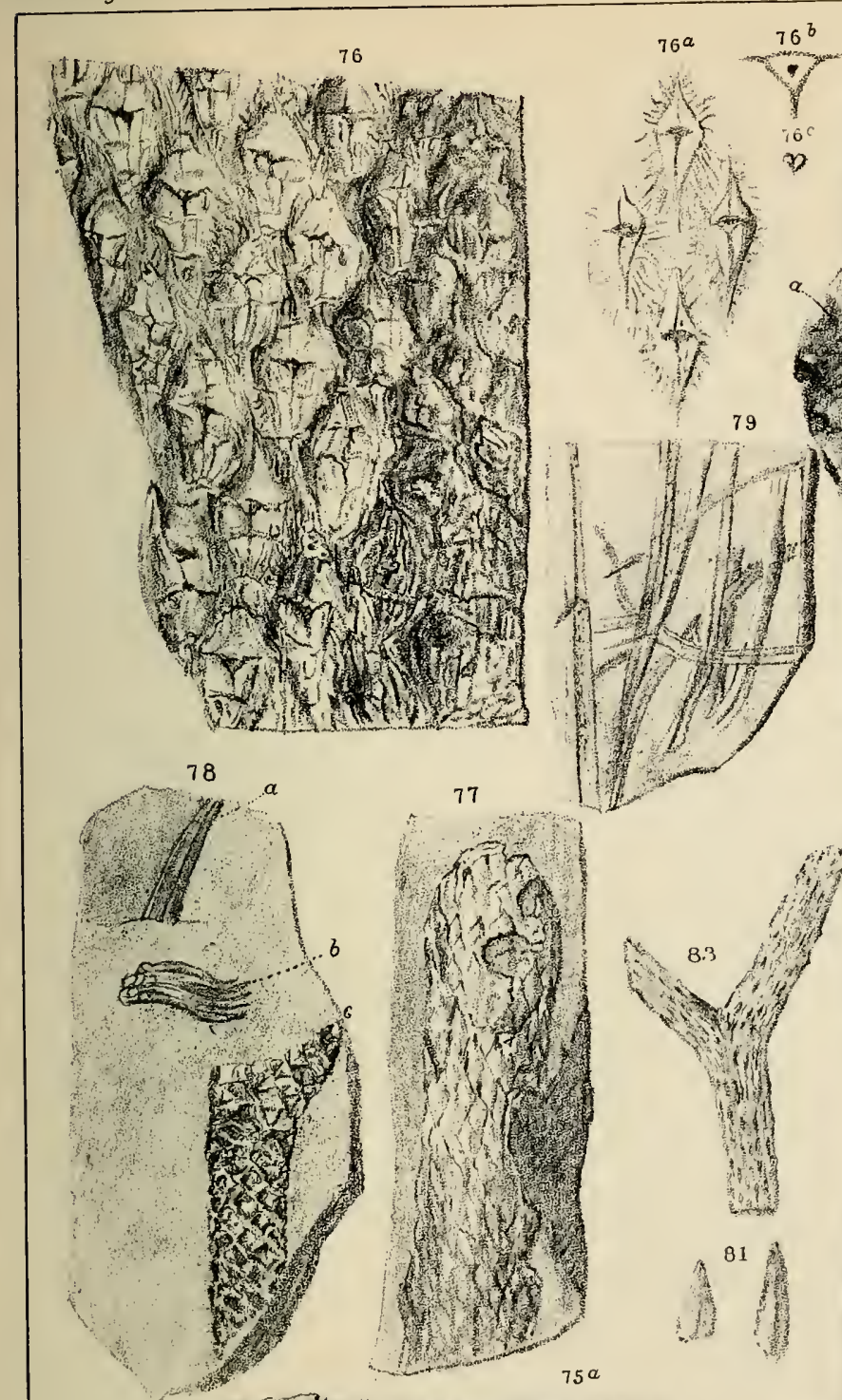

80

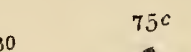

$75^{b}$

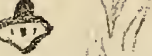
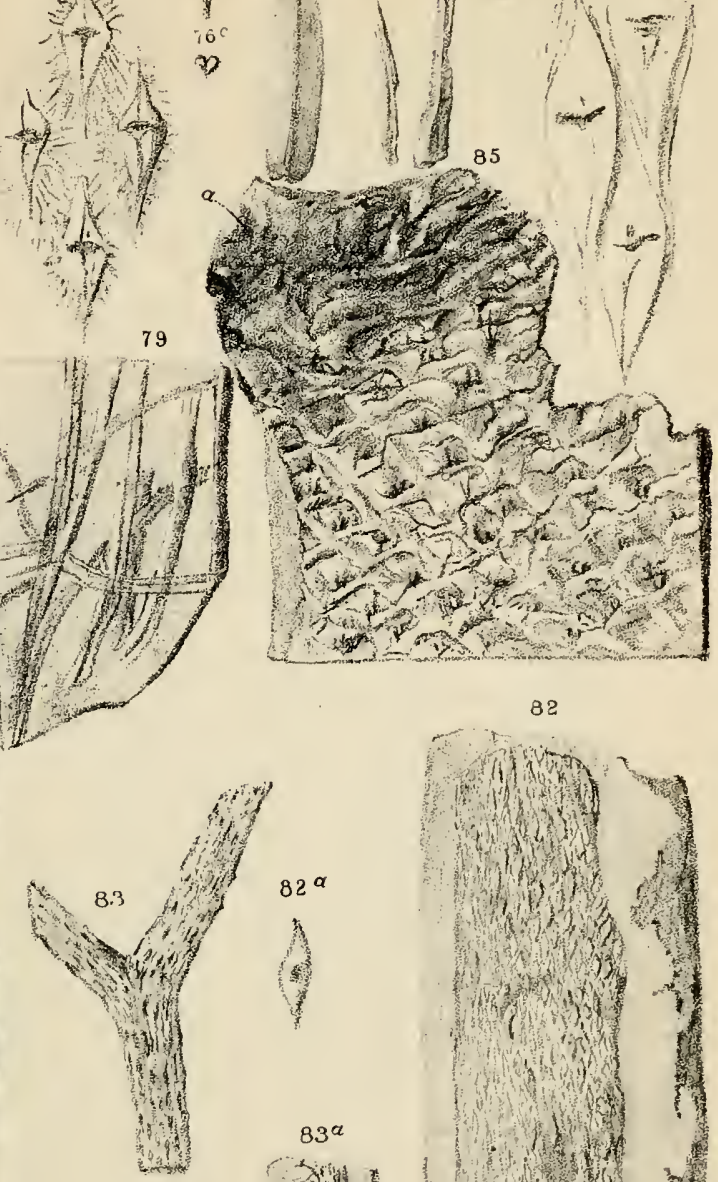

82

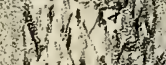

$p+11$

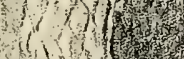

Hil

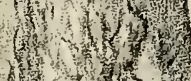

and

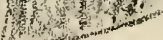

$4^{81}$

$83^{a}$

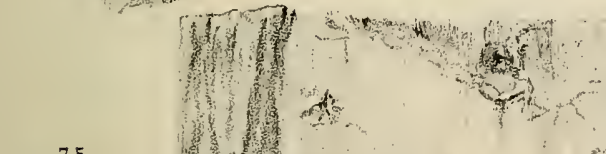

$75^{a}$

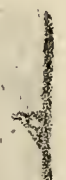

\section{Ther}

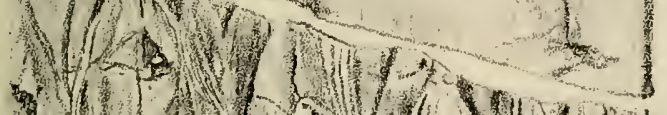

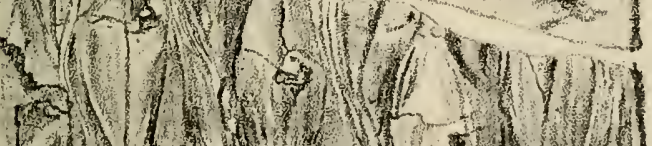
$710 \times 17$

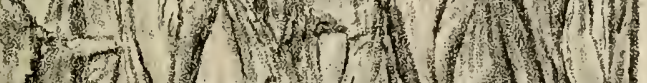
$17 N \times$ N 2n M Ma. 910

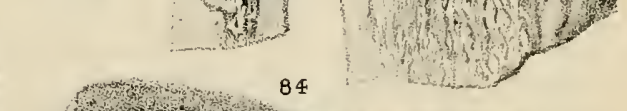

1010101019 b ta. e 11 (10) 1) 180 1.101021 Hen 



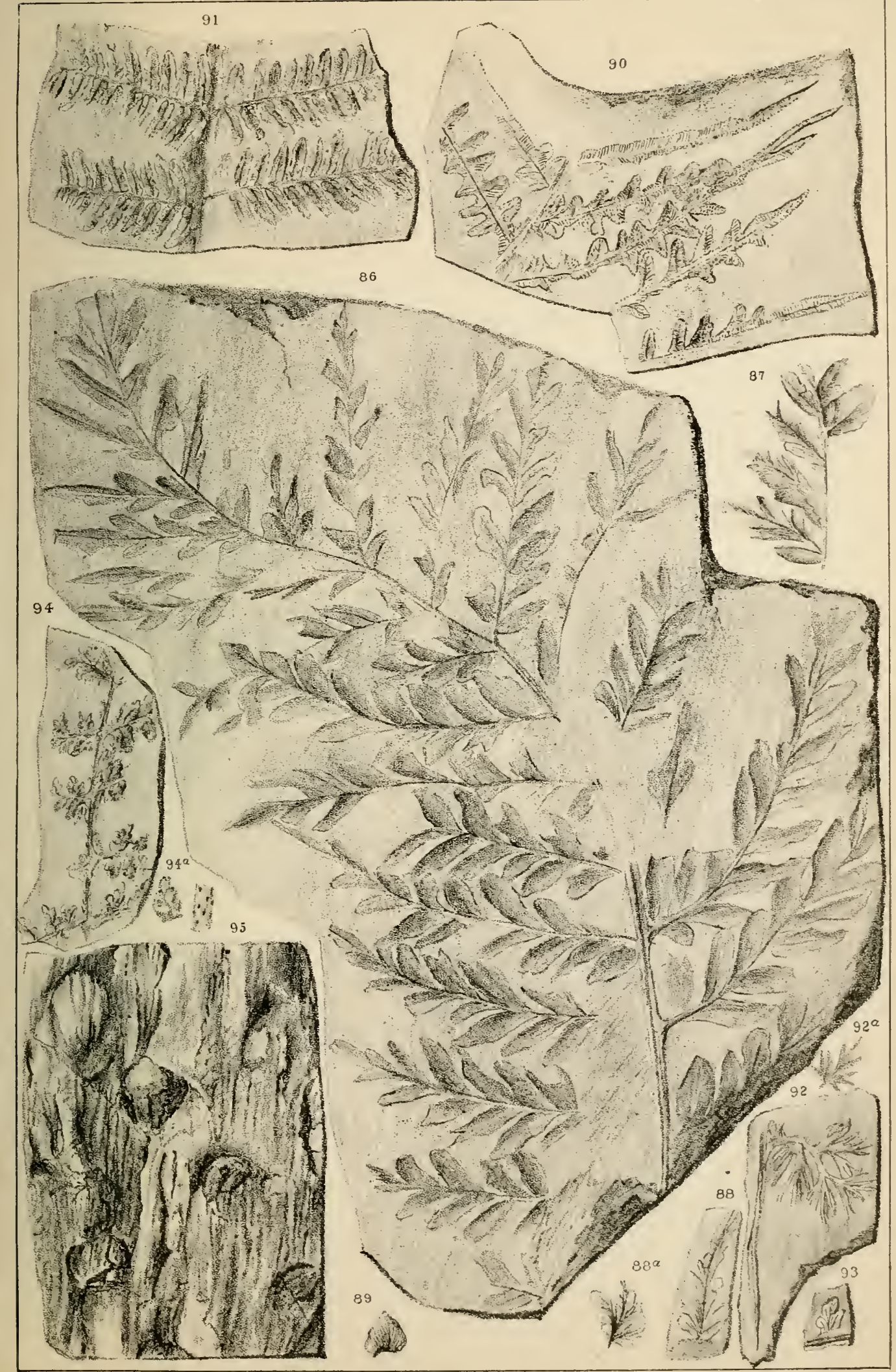




$$
\text { . }
$$ 



\section{DATE DUE}

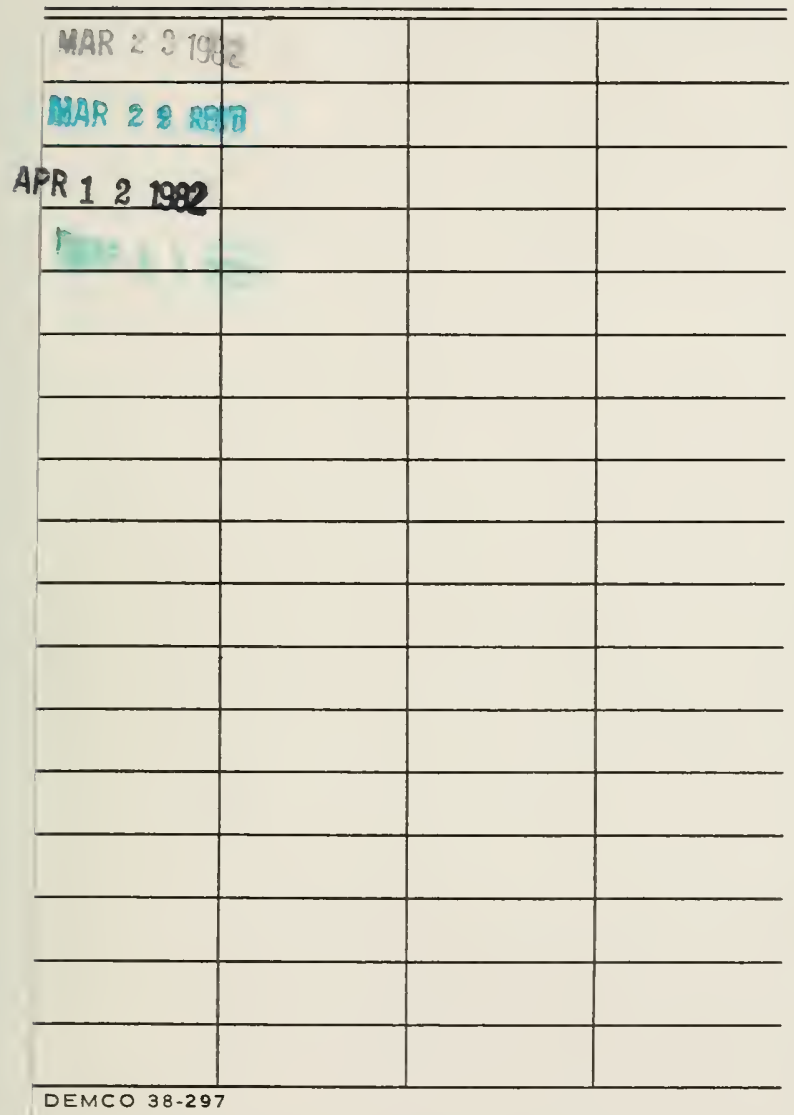


!
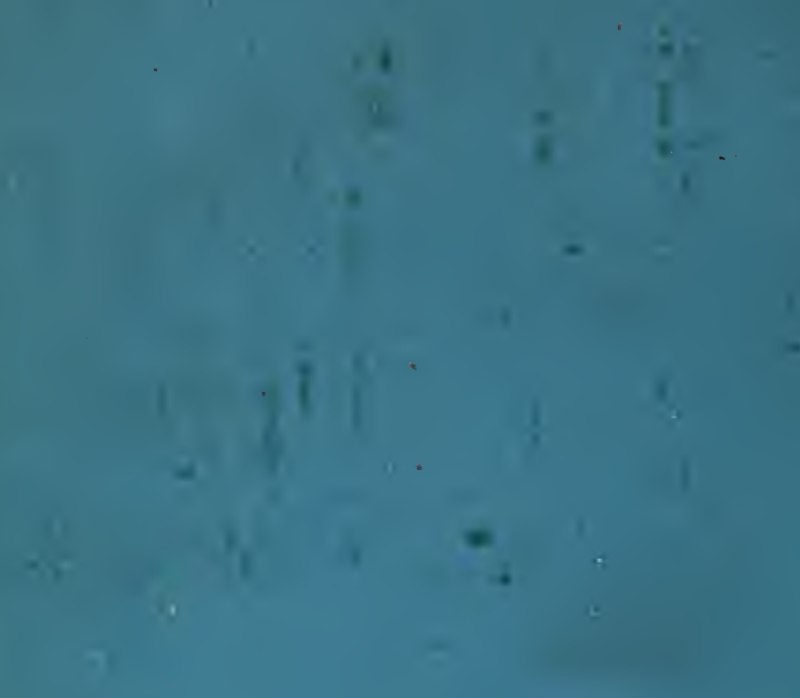